\title{
Purinergic Signalling in Allogeneic Haematopoietic Stem Cell Transplantation and Graft-versus-Host Disease
}

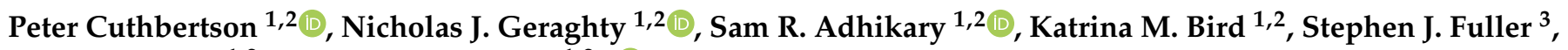 \\ Debbie Watson ${ }^{1,2, *}$ and Ronald Sluyter $1,2, *$ (D) \\ 1 Illawarra Health and Medical Research Institute, Wollongong, NSW 2522, Australia; \\ pc859@uowmail.edu.au (P.C.); geraghty@uow.edu.au (N.J.G.); Sam.Adhikary@qimrberghofer.edu.au (S.R.A.); \\ kb215@uowmail.edu.au (K.M.B.) \\ 2 Molecular Horizons and School of Chemistry and Molecular Bioscience, University of Wollongong, \\ Wollongong, NSW 2522, Australia \\ 3 Sydney Medical School Nepean, University of Sydney, Nepean Hospital, Penrith, NSW 2747, Australia; \\ stephen.fuller@sydney.edu.au \\ * $\quad$ Correspondence: dwatson@uow.edu.au (D.W.); rsluyter@uow.edu.au (R.S.); Tel.: +61-2-4221-5508 (R.S.)
}

\section{check for} updates

Citation: Cuthbertson, P.; Geraghty, N.J.; Adhikary, S.R.; Bird, K.M.; Fuller, S.J.; Watson, D.; Sluyter, R. Purinergic Signalling in Allogeneic

Haematopoietic Stem Cell

Transplantation and

Graft-versus-Host Disease. Int. J. Mol. Sci. 2021, 22, 8343. https://doi.org/ $10.3390 /$ ijms 22158343

Academic Editors: Tomomi Toubai and Timothy Devos

Received: 13 July 2021

Accepted: 29 July 2021

Published: 3 August 2021

Publisher's Note: MDPI stays neutral with regard to jurisdictional claims in published maps and institutional affiliations.

Copyright: (c) 2021 by the authors. Licensee MDPI, Basel, Switzerland. This article is an open access article distributed under the terms and conditions of the Creative Commons Attribution (CC BY) license (https:/ / creativecommons.org/licenses/by/ $4.0 /)$.

\begin{abstract}
Allogeneic haematopoietic stem cell transplantation (allo-HSCT) is a curative therapy for blood cancers and other haematological disorders. However, allo-HSCT leads to graft-versus-host disease (GVHD), a severe and often lethal immunological response, in the majority of transplant recipients. Current therapies for GVHD are limited and often reduce the effectiveness of allo-HSCT. Therefore, pro- and anti-inflammatory factors contributing to disease need to be explored in order to identify new treatment targets. Purinergic signalling plays important roles in haematopoiesis, inflammation and immunity, and recent evidence suggests that it can also affect haematopoietic stem cell transplantation and GVHD development. This review provides a detailed assessment of the emerging roles of purinergic receptors, most notably $\mathrm{P} 2 \mathrm{X} 7, \mathrm{P}_{2} \mathrm{Y}_{2}$ and $\mathrm{A}_{2 \mathrm{~A}}$ receptors, and ectoenzymes, CD39 and CD73, in GVHD.
\end{abstract}

Keywords: P2X7 receptor; P2Y receptor; adenosine receptor; CD39; CD73; ATP

\section{Introduction}

Blood cancers are a highly complex group of disorders that arise from the malignant transformation of cells of the blood, bone marrow or lymphatic system. These malignancies account for approximately $10 \%$ of all cancers worldwide [1]. Allogeneic haematopoietic stem cell transplantation (allo-HSCT) is a curative therapy for blood cancers and other haematological disorders [2]. Allo-HSCT has dual beneficial effects. First, it restores the immune system of the recipient that has been diminished by myeloablative therapy. Second, donor cells provide anti-tumour immunity known as the graft-versus-tumour (GVT) effect to prevent malignant disease relapse. However, allo-HSCT also causes graftversus-host disease (GVHD) in the majority of recipients [3]. GVHD is a severe and often lethal immunological response against host tissues, mediated by donor $\mathrm{T}$ cells $[4,5]$. Therapies for GVHD are currently limited to broad range immunosuppression and prophylactic T cell depletion strategies, however cancer relapse is still a major cause of mortality [6]. Therefore, new and better treatment options that limit GVHD but maintain the GVT effect, need to be explored. This requires a deeper understanding of which factors contribute to GVHD following allo-HSCT.

Purinergic signalling is a form of cell-to-cell communication involving extracellular nucleosides and nucleotides, and their respective cell surface receptors, with roles in health and disease [7]. Recent evidence indicates roles for these receptors in both allo-HSCT and GVHD. Thus, molecules of the purinergic signalling pathway are emerging as potential therapeutic targets for preventing GVHD development and progression in allo-HSCT 
recipients. This review will present a brief overview of allo-HSCT including the GVT effect and GVHD, and purinergic signalling. This review will then provide a detailed assessment of our current understanding of the roles of purinergic receptors and other molecules in GVHD.

\section{Allogeneic Haematopoietic Stem Cell Transplantation and the Graft-Versus- Tumour Effect}

Allo-HSCTs were first performed over 50 years ago [8,9] and this treatment is now a well-established therapeutic option for patients with haematological malignancies [2] In general, allo-HSCT is used to replace an abnormal non-malignant haematopoietic system with haematopoietic stem cells (HSCs) from a healthy donor, or to enable higher doses of myeloablative therapy to treat malignancy. Allo-HSCT is possible because of the ability of the HSCs to home to the bone marrow and replace the entire haematopoietic system after intravenous injection [10]. Prior to allo-HSCT, the recipient receives myeloablative chemotherapy and/or radiotherapy that is designed to eradicate the underlying disease and immunosuppress the patient to prevent immunologically mediated rejection of the transplanted donor HSCs [11,12]. Bone marrow cells or peripheral blood HSCs collected from the donor are infused into the recipient [13]. The donor HSCs "home" to the site of bone marrow in the recipient and engraft in their new haematopoietic microenvironment [13]. Following myeloablative therapy, peripheral blood cell counts decrease over several days and haematopoietic growth factors are administered to the patient to increase the rate of donor stem cell engraftment [14]. Transplanted stem cells start to appear after a week and blood counts fully recover after three to four weeks [14].

A major therapeutic benefit of allo-HSCT is the GVT effect. GVT was first demonstrated in a murine model where allo-HSCT eradicated residual leukaemia but also caused a fatal "wasting syndrome" characterised by diarrhoea [15], now recognised as GVHD. The GVT effect has since been defined in considerable detail in allogeneic $[16,17]$ and humanised mouse models [18-20], and has been translated to human studies [21,22]. It is now widely appreciated that the GVT effect is one of the most effective and clinically successful forms of immunotherapy following allo-HSCT.

Allogeneic mouse models are commonly used to study the GVT effect and involve the transplantation of bone marrow or splenocytes from C57BL/6 mice to BALB/c mice, followed by transplantation of cancer cells such as A20 or BCL1 murine lymphoma cells $[16,17]$. These models have been used to demonstrate that $\mathrm{CD} 8^{+} \mathrm{T}$ cells are the main drivers of the GVT effect [17]. Humanised mouse models involving the transplantation of human peripheral blood mononuclear cells (PBMCs) and human cancer cells, such as THP-1 acute monocyte leukaemia cells, have been used to examine the role of human immune cells in GVT immunity $[19,20]$.

Despite the life-saving benefits of the GVT effect, $\mathrm{T}$ cells that are transfused with the graft can also react against tissues of the genetically different recipient causing GVHD, which affects mainly the skin, liver, and gastrointestinal tract but may also target other organs [23]. The major determinant for alloreactivity and choosing an allogeneic donor is the degree of matching at loci in the major histocompatibility complex (MHC) which includes human leukocyte antigens (HLA) encoded by MHC class I and class II genes. The two major approaches to preventing acute GVHD are pharmacologic immunosuppression, commenced early after allo-HSCT, and T cell depletion of the donor graft, however despite prophylaxis approximately $30 \%$ of recipients of stem cells from matched siblings and up to $50 \%$ from unrelated donors will develop acute GVHD, and chronic GVHD is seen in $30-70 \%$ of recipients $[3,24,25]$.

\section{Acute Graft-versus-Host Disease}

Acute GVHD, hereafter referred to as GVHD (unless stated otherwise), has a complex pathophysiology, which initially begins with damage to host tissue by the myeloablative therapy used in allo-HSCT. This causes the release of damage-associated molecular patterns, including adenosine $5^{\prime}$-triphosphate (ATP), which promote the maturation of host dendritic 
cells (DCs) through up-regulation of MHC class I and class II molecules [26]. Host DCs then activate donor T cells in the graft, which migrate to GVHD target organs and release pro-inflammatory cytokines, including interferon (IFN)- $\gamma$ [27] and interleukin (IL)-17 which drive inflammatory damage [28]. Although donor $\mathrm{CD}^{+}$and $\mathrm{CD}^{+} \mathrm{T}$ cells are the main mediators of GVHD [4,5], there are several other immune cell subsets involved in its pathogenesis. Neutrophils are associated with intestinal GVHD $[29,30]$ and macrophages contribute to acute and chronic GVHD pathogenesis [31]. Conversely regulatory T cells (Tregs) are important for preventing GVHD development in allo-HSCT recipients [32,33]. Natural killer $(\mathrm{NK})$ cells can have regulatory $[34,35]$ or pathogenic $[36,37]$ roles in GVHD, but are also important for mediating the GVT effect [38]. As a result of this complex pathophysiology current treatments have limited success. Therefore, pre-clinical GVHD models are important tools for identifying novel therapeutics.

As for the GVT studies above, allogeneic mouse models have been the main method used to investigate GVHD, providing vast insight into the pathophysiology of the disease [39]. These mouse models of GVHD typically involve transferring $\mathrm{T}$ cell depleted bone marrow, with splenocytes (as a source of T cells) or purified T cells, from one mouse strain (donor) into a second mouse strain (recipient) that has been lethally irradiated. These models have been integral in identifying the role of immune cells and cellular signalling pathways involved in GVHD and testing of therapeutic agents. However, these therapies have not always translated to the clinic due to the inability of GVHD mouse models to fully replicate human immune responses.

This limitation is partially overcome with the use of humanised mouse models of GVHD, which involve the transfer of human immune cells, or tissue, into immunodeficient mice [39]. This immunodeficiency allows the engraftment of human immune cells, and the development of a functional human immune system in these mice. Two mouse strains commonly used for humanised models of GVHD are NOD.Cg-Prkdc scid Il2rgrull (NSG) and NOD.Cg-Prkdc $c^{\text {scid }} I l 2 r g^{\text {tm1Sug }}$ (NOG). These strains are near-identical, except the former encodes a complete null mutation in the $I l 2 \mathrm{rg}$ gene and the latter an $I l 2 \mathrm{rg}$ gene mutation giving rise to a non-functional IL-2 receptor [40]. These mice are typically injected with human PBMCs, initiating $\mathrm{CD}^{+}$and $\mathrm{CD}^{+} \mathrm{T}$ cell-mediated GVHD [41,42]. GVHD in humanised mice mediates damage to the same tissues as observed in humans, namely the skin, liver, gastrointestinal tract and lungs [42-45]. These models are useful for pre-clinical investigations of novel therapeutic strategies for GVHD such as the adoptive transfer of Tregs $[46,47]$ or T cell depletion strategies $[48,49]$. However, current treatment options do not always prevent GVHD or cancer relapse, so new therapeutics that retain the GVT effect but prevent GVHD are needed.

\section{Purinergic Signalling}

Purinergic signalling is a form of cell-to-cell communication comprising a network of extracellular nucleotides and nucleosides, cell surface receptors, ecto-enzymes and nucleotide release pathways [50]. Purinergic signalling is important in various physiological systems [7] including the immune system [51]. This network is comprised of P1 receptors activated by extracellular adenosine, and $\mathrm{P} 2$ receptors typically activated by extracellular ATP but in some cases by other extracellular nucleotides [50]. Adenosine receptors are G-protein coupled receptors comprising four subtypes $\left(A_{1}, A_{2 A}, A_{2 B}\right.$ and $\mathrm{A}_{3}$ ) [52]. P2 receptors comprise two subclasses: P2X and P2Y. P2X receptors are trimeric ligand-gated ion channels comprising seven subunits (P2X1, P2X2, P2X3, P2X4, P2X5, P2X6 and P2X7), which can assemble as homomeric or heteromeric channels [53]. P2Y receptors are G-protein coupled receptors comprising eight subtypes $\left(\mathrm{P}_{2} \mathrm{Y}_{1}, \mathrm{P}_{2} \mathrm{Y}_{2}, \mathrm{P}_{2} \mathrm{Y}_{4}, \mathrm{P}_{2} \mathrm{Y}_{6}, \mathrm{P}_{2} \mathrm{Y}_{11}\right.$, $\mathrm{P}^{2} \mathrm{Y}_{12}, \mathrm{P}_{2} \mathrm{Y}_{13}$ and $\left.\mathrm{P} 2 \mathrm{Y}_{14}\right)[54,55]$.

Cells release nucleotides and nucleosides by specific (hemichannels, transporters, microvesicles and exocytosis) and non-specific pathways (cell stress and cell death) [7]. The availability of extracellular nucleotides is further controlled by cell-surface adenylate kinase and nucleoside diphosphate kinases, which convert extracellular adenosine 
$5^{\prime}$-monophosphate (AMP) to adenosine $5^{\prime}$-diphosphate (ADP) and ATP, as well as a cellsurface ATP synthase [56,57]. The amount of extracellular nucleotides and nucleosides can also be regulated by ecto-nucleotidases, which hydrolyse nucleotides and nucleosides, and comprise the ecto-nucleoside triphosphate diphosphohydrolase (E-NTPDase), ecto5 '-nucleotidase, ecto-nucleotide pyrophosphatase/phosphodiesterase, and alkaline phosphatase families $[56,57]$. Of these enzymes, ecto-nucleoside triphosphate diphosphohydrolase 1 (E-NTPDase1/CD39), which hydrolyses ATP/ADP to AMP, and ecto-5'-nucleotidase (CD73), which hydrolyses AMP to adenosine, play central roles in inflammation and immunity [58].

\section{Purinergic Signalling in Allogeneic Haematopoietic Stem Cell Transplantation}

This review focuses on the role of purinergic signalling in GVHD including the use of pharmacological agents and genetic approaches to explore this role. However, purinergic signalling also has multiple roles in allo-HSCT, which will be discussed briefly first. Purinergic signalling modulates haematopoiesis and HSCs impacting cell homeostasis, differentiation, mobilisation and death (reviewed by [59-61]). P2X and P2Y receptors are found in all haematopoietic cell types, including lymphoid and myeloid cells [61]. Adenosine receptors, and CD39 and CD73 are also found on a range of haematopoietic cells but most prominently on immune cells $[58,62]$. While HSCs reside in the bone marrow niche, there are also circulating HSCs that play an important role in sensing danger signals from inflammatory damage or injury [61]. Collectively, this evidence supports a role for purinergic signalling in allo-HSCT.

A link between extracellular nucleotides such as ATP and mobilisation of HSCs has been shown with the P2 receptors and NLRP3 inflammasome being involved in the mobilisation of HSCs to the peripheral blood [63]. In particular, ATP and P2X7 play a role in haematopoiesis and mobilisation of HSCs, and trafficking of granulocytes and monocytes [60]. Supporting this, HSCs with single nucleotide polymorphisms (SNPs) (rs2230912 and rs1718119) in the P2RX7 gene (Q460R and A348T, respectively) show an increase in CD34 ${ }^{+}$HSC mobilisation [64]. Further, studies have demonstrated that ATP promotes, and adenosine inhibits, the migration of HSCs $[65,66]$. Uridine $5^{\prime}$-triphosphate (UTP) stimulation of P2Y receptors can also increase the migration of HSCs [67] and P2Y 14 has been shown to modulate HSCs under stressful conditions [68]. CD39 and CD73 are also highly expressed on HSCs [69]. Adenosine generated by CD39 on CD150high Tregs in the bone marrow niche can control HSC quiescence, and both CD150 high conventional $\mathrm{CD}^{+} \mathrm{T}$ cells and Tregs can modulate HSCs via CD73 [70]. CD73 knockout mice show increased HSC mobilisation compared to wild-type (wt) mice [65]. Therefore, CD39 and CD73 prevent ATP-mediated differentiation of HSCs by degrading ATP to adenosine, a negative feedback loop, which leads to maintaining HSCs in a quiescent state via $A_{2 A}$ activation $[65,70]$.

Purinergic signalling also plays an important role in allo-HSCT. Prior to transplant, granulocyte-colony stimulating factor (G-CSF) mobilisation of HSCs to peripheral blood makes HSCs easily accessible and improves engraftment [71]. However, some individuals do not mobilise adequate numbers of HSCs and strategies to generate more efficient protocols are required [60]. In humans, lower P2X7 expression is associated with lower HSC mobilisation following G-CSF [64]. Pre-conditioning regimes, including chemotherapy and radiotherapy, prior to allo-HSCT may also result in tissue damage and release of danger signals, including ATP, that activate purinergic signalling pathways [72,73].

ATP and its analogues can impact HSC differentiation and engraftment, and play a role in trafficking of HSCs to bone marrow niches following allo-HSCT [60]. Pannexin-1mediated release of ATP is also important for HSC trafficking, with pannexin-1 blockade leading to defects in HSC homing and engraftment in mice [74]. Therefore, targeting pathways associated with purinergic signalling including the NLRP3 inflammasome, pannexin1 or P2X7 to reduce inflammatory immune responses or targeting CD39 or CD73 that 
hydrolyse extracellular ATP to adenosine to promote immunosuppression may improve HSC engraftment and allo-HSCT outcomes.

Identifying SNPs in genes encoding the NLRP3 inflammasome complex, P2X receptors, CD39 (ENTPD1) or CD73 (NT5E) may establish important predictive or prognostic markers for allo-HSCT outcomes. Donor and recipient SNP variants in the NLRP3 gene have been examined in HLA-identical sibling allo-HSCT, with only the donor rs10925027 intronic TT genotype being associated with disease relapse [75]. Studies of P2RX7 SNPs in both donor and recipients of allo-HSCT have shown limited effects on allo-HSCT outcomes. A small cohort showed that the loss-of-function (LOF) rs3751143 P2RX7 SNP (E496A) in homozygous doses was associated with poorer overall survival [76], but this was not replicated in a larger study [77]. More recently a study examined 16 P2RX7 SNPs in alloHSCT donors and recipients [78]. Although limited by sample size, this study revealed that the missense rs3751143 P2RX7 SNP in homozygous dosage may be associated with overall survival, while the rare LOF rs1653624 P2RX7 SNP (I568N) may be associated with reduced survival due to infection-related deaths. These studies indicate that P2RX7 (P2X7) SNPs are unlikely to be biomarkers or predictors of allo-HSCT outcome. To the best of our knowledge there are no reports examining human donor and recipient ENTPD1 (CD39), NT5E (CD73) and ADORA2A $\left(\mathrm{A}_{2 \mathrm{~A}}\right)$ genotypes and allo-HSCT outcomes in the clinical setting. Finally, it should be noted that purinergic receptors and molecules play emerging roles in blood cancer cells $[79,80]$, but this is beyond the scope of this review.

\section{Purinergic Signalling in GVHD}

Purinergic signalling has an important role in the progression of GVHD which has been largely elucidated through the use of pharmacological agents as well as knockout mice. The purinergic molecules often highlighted as playing key roles in inflammation and immunity, namely $\mathrm{A}_{2 \mathrm{~A}}, \mathrm{P} 2 \mathrm{X7}, \mathrm{P}_{2} \mathrm{Y}_{2}, \mathrm{CD} 39$ and CD73 [81], are also those associated with the promotion or prevention of GVHD [26,82]. The distribution and roles of these purinergic molecules in the immune system were recently reviewed $[81,83]$. In general, these molecules can combine to form a hypothetical pathway of cellular activation and regulation within the immune system (Figure 1). ATP released during inflammation and cell damage can stimulate P2X7 on leukocytes to drive various inflammatory events such as DC migration [84], pro-inflammatory cytokine release from macrophages and DCs [85], and effector T cell activation [86]. Additionally, UTP can be released along with ATP to activate $\mathrm{P}^{2} \mathrm{Y}_{2}$ to further promote leukocyte migration $[87,88]$ and cytokine release $[89,90]$. ATP can be sequentially degraded by CD39 and CD73 to yield adenosine, thereby activating $\mathrm{A}_{2 \mathrm{~A}}$ on leukocytes and resulting in the impairment of inflammatory events such as reduced pro-inflammatory cytokine release from $\mathrm{T}$ cells $[91,92]$. 


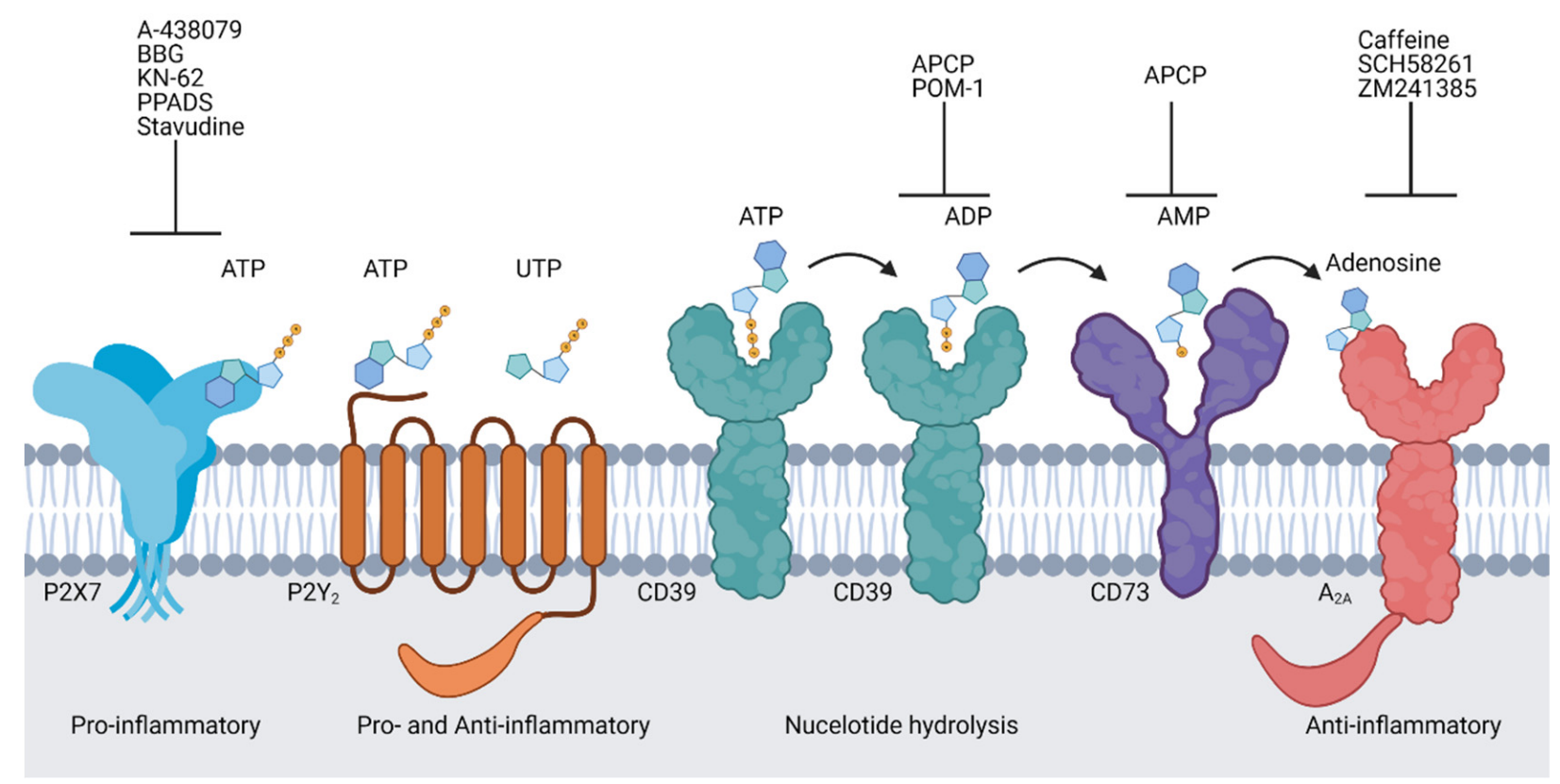

Figure 1. Purinergic signalling molecules associated with graft-versus-host disease. The purinergic receptors $\mathrm{P} 2 \mathrm{X} 7, \mathrm{P} 2 \mathrm{Y}_{2}$ and $\mathrm{A}_{2 \mathrm{~A}}$ are activated by adenosine $5^{\prime}$-triphosphate (ATP), uridine triphosphate (UTP)/ ATP or adenosine, respectively. P2X7 plays a pro-inflammatory role and $\mathrm{A}_{2 \mathrm{~A}}$ plays an anti-inflammatory role while $\mathrm{P}_{2} \mathrm{Y}_{2}$ may be involved in both roles. CD39 converts ATP to adenosine $5^{\prime}$-diphosphate (ADP) and ADP to adenosine $5^{\prime}$-monophosphate (AMP). CD73 converts AMP to adenosine. Antagonists for P2X7 (A-438079, Brilliant blue G (BBG), KN-62, and pyridoxalphosphate-6-azophenyl2', 4'-disulfonic acid (PPADS) and stavudine), CD39 ( $\alpha, \beta$-methylene ADP (APCP) and polyoxotungstate-1 (POM-1)), CD73 (APCP) and $\mathrm{A}_{2 \mathrm{~A}}$ (Caffeine, SCH58261 and ZM241385) have been used to study the roles of these molecules in GVHD. Created with BioRender.com.

A number of compounds have been studied that inhibit purinergic signalling molecules $[81,83]$, however interpretation of the effects of these antagonists in both in vitro and in vivo settings is not straightforward. For example, the efficacy of $A_{2 A}$ and P2X7 antagonists differs between species [93,94], which is relevant when studying humanised mouse models of GVHD. Furthermore, it should be noted that inhibitors such as caffeine are non-selective adenosine receptor antagonists, impairing the activity of all four subtypes [93]. Similarly, pyridoxalphosphate-6-azophenyl-2', 4'-disulfonic acid (PPADS) and Brilliant Blue G (BBG) are non-selective P2X7 antagonists that inhibit the majority of P2X

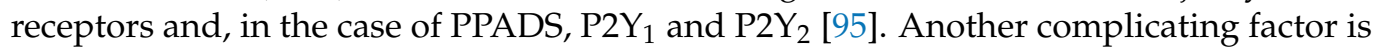
that both A-438079 and BBG impair the ATP-release channel, pannexin-1 [96], and this may impair P2X7-mediated responses by blocking both P2X7 activation and reducing extracellular ATP. KN-62 was originally developed as a calmodulin-dependent protein kinase II antagonist [97] but was subsequently shown to potently inhibit P2X7 [98]. Stavudine is a nucleoside reverse transcriptase inhibitor [99] that impairs P2X7 pore formation but not channel activity [100]. However, a comprehensive pharmacological characterisation of this compound against P2X7 is lacking. Of note, a second nucleoside reverse transcriptase inhibitor, azidothymidine (Zidovudine) [99], binds to the allosteric binding site of P2X7 and impairs P2X7-mediated calcium fluxes and dye uptake in myoblasts [101].

In addition, the action and specificity of the ecto-enzyme inhibitors, $\alpha, \beta$-methylene ADP (APCP) and polyoxotungstate-1 (POM-1) used in studies of GVHD, have not been completely defined. APCP is commonly regarded as an inhibitor of CD73, with in vitro enzymatic data showing it does not impair CD39 [102]. In contrast, one study has demonstrated that this compound can inhibit human CD39 heterologously expressed in HEK293 cells [103]. It remains to be determined if APCP can directly impair CD39 from other species, however APCP impairment reversed the extended thrombosis time in human CD39 expressing $\mathrm{N} t 5 e^{-/-}$transgenic mice [103]. APCP can also modulate P2Y receptor 
activation [104] further complicating its use in vivo. Finally, POM-1, an inhibitor of CD39 and other NTPDases [105] can also block P2X- and P2Y-mediated calcium responses in macrophages, and impair some but not all features of P2X7 activation in these cells [106], again muddling its use in vivo.

A further limitation to past studies of purinergic signalling in GVHD has been the use of the compounds above in the absence of routine clinical GVHD therapies including corticosteroids and other drugs. However, the interaction of these clinical drugs with purinergic pathways involved in GVHD is largely unknown but remains a possibility. In this regard, the corticosteroid prednisone has been shown to reduce both P2X7 in PBMCs from a patient with the inflammatory disorder Schnitzler's syndrome [107] and P2X3 in the joints of rats with inflammatory arthritis [108]. Furthermore, a study of asthma patients revealed that those with low P2X7 activity were less likely to benefit from inhaled corticosteroids [109]. Thus, a potential relationship may also exist between purinergic pathways and corticosteroid therapy failure in patients with GVHD.

\section{P2X7 Receptor Signalling in GVHD}

There is increasing evidence that ATP and P2X7 play important roles in GVHD development. This evidence comes from studies examining the effects of ATP degradation, P2X7 expression in murine and human GVHD, P2X7 receptor blockade, and comparisons in P2X7 knockout mice or humans with P2XR7 SNPs. Together the evidence indicates that the ATP/P2X7 signalling axis initiates pro-inflammatory effects by activating host DCs and causing dysfunction and/or destruction of cells with suppressor activity.

Studies of allogeneic and humanised mouse models indicate a role for extracellular ATP in promoting GVHD (Table 1). ATP is increased in the peritoneal fluid of allo-HSCT patients with GVHD compared to allo-HSCT recipients without GVHD [72]. ATP is also increased in the peritoneal fluid shortly after pre-conditioning and increased in the gut during disease progression in an allogeneic mouse model of GVHD [72,110]. Apyrase, a soluble ATP diphosphohydrolase (ATPDase), injected during the first week post-transplantation reduced apoptosis and inflammation in target organs and serum IFN- $\gamma$, and increased survival in an allogeneic mouse model of GVHD [72,110] indicating a direct role for extracellular ATP in mediating GVHD progression following pre-conditioning and transplantation. Indirect evidence for extracellular ATP in GVHD is also revealed through the pharmacological blockade of the CD39/CD73 pathway, which results in increased or sustained extracellular ATP concentrations. Blockade of CD39/CD73 with APCP (days 0-6 or twice weekly) reduced survival, increased $\mathrm{T}$ cell proliferation and pro-inflammatory cytokines, and increased GVT immunity in an allogeneic mouse model [111,112]. Furthermore, treatment with APCP (days 0-6) in a humanised mouse model of GVHD, which does not involve pre-conditioning, resulted in worsened disease with increased weight loss, liver apoptosis and serum human IL-2 [113]. This latter finding supports the notion that ATP is released during GVHD progression and that the initial pre-conditioning regime used in allogeneic mouse studies is not essential for ATP release.

The majority of studies to date indicate that $\mathrm{P} 2 \mathrm{X} 7$ is the major $\mathrm{P} 2 \mathrm{X}$ receptor involved in GVHD progression following ATP release. Human P2RX7 expression is increased in the PBMCs of human patients with GVHD, compared to allo-HSCT recipients without GVHD or healthy controls [72]. Whilst mouse P2rx7 expression is increased in the liver, spleen and thymus of allogeneic mice with GVHD [72,114], and in the duodenum, ileum and skin of humanised mice with GVHD [45]. Moreover, P2X7 protein is increased on antigen presenting cells (APCs) in Peyer's patches and in the colon of patients with GVHD [72]. This increase in P2X7 on APCs may be dependent on mir-188 expression, as deficiency of this microRNA results in decreased P2rx7 in murine DCs, corresponding to decreased GVHD in mir-188 knockout recipients [115]. Murine P2rx4 is also increased in the gut and skin of humanised mice with GVHD [45], but a role for P2X4 in this disease remains to be investigated. 
Table 1. Extracellular ATP degradation and blockade of CD39 and CD73 in mouse models of graft-versus-host disease.

\begin{tabular}{|c|c|c|c|c|c|c|}
\hline Model & Graft & Host & Target & Drug Regime & Outcomes & Ref. \\
\hline Allogeneic & $\begin{array}{l}5 \times 10^{6} \mathrm{TCD}^{\mathrm{a}} \mathrm{BM}^{\mathrm{b}} \text { cells }+1.6 \\
\times 10^{6}(\mathrm{FVB} / \mathrm{N}) \text { or } 1 \times 10^{6} \\
\mathrm{CD} 4^{+} / \mathrm{CD}^{+}(\mathrm{C} 57 \mathrm{BL} / 6) \\
\left(\text { i.v. }{ }^{\mathrm{c}}\right)\end{array}$ & $\mathrm{BALB} / \mathrm{c}$ & eATP ${ }^{d}$ & $\begin{array}{l}4 \mathrm{U} \text { Apyrase (hydrolysis } \\
\text { catalyst) i.p. e days 0-2, } \\
6-8\end{array}$ & $\begin{array}{l}\uparrow^{\mathrm{f}} \text { Survival } \\
\downarrow^{\mathrm{g}} \text { Apoptosis and } \\
\text { inflammation in the } \\
\text { gastrointestinal tract } \\
\downarrow \text { Serum IFN }{ }^{\mathrm{h}}-\gamma\end{array}$ & [72] \\
\hline Allogeneic & $\begin{array}{l}10 \times 10^{6} \mathrm{CD} 25 \text { depleted } \mathrm{T} \\
\text { cells }(\mathrm{C} 57 \mathrm{BL} / 6)(\text { injection } \\
\text { route not disclosed) }\end{array}$ & $\mathrm{BALB} / \mathrm{c}$ & eATP & $\begin{array}{l}4 \mathrm{U} \text { Apyrase (hydrolysis } \\
\text { catalyst) i.p. days } 0-4\end{array}$ & $\uparrow$ Survival & [110] \\
\hline Allogeneic & $\begin{array}{l}5 \times 10^{6} \mathrm{BM} \text { cells and } 2 \times 10^{5} \\
\mathrm{CD} 4^{+} / \mathrm{CD}^{+} \text {splenic T cells } \\
\text { (i.v.) }\end{array}$ & C57BL/ 6 & CD73 & $\begin{array}{l}50 \mathrm{mg} / \mathrm{kg} \mathrm{APCP}{ }^{\mathrm{i}} \\
\text { (antagonist) i.p. days 0-6 }\end{array}$ & $\uparrow$ Mortality & [111] \\
\hline Allogeneic & $\begin{array}{l}5 \times 10^{6} \text { BALB } / \text { c splenocytes } \\
\pm \text { BM cells or splenocytes (i.v.) }\end{array}$ & C57BL/ 6 & CD73 & $\begin{array}{l}20 \mathrm{mg} / \mathrm{kg} \text { APCP } \\
\text { (antagonist) i.v. twice } \\
\text { weekly }\end{array}$ & $\begin{array}{l}\uparrow \text { Mortality } \\
\uparrow \text { Splenic CD4 } 4^{+} \text {and CD8 }{ }^{+} \mathrm{T} \\
\text { cells } \\
\uparrow \text { Serum IFN- } \gamma \text { and IL }-6 .\end{array}$ & [112] \\
\hline Humanised & $10 \times 10^{6}$ hPBMCs $^{\mathrm{k}}$ (i.p.) & $\mathrm{NSG}^{1}$ & CD39 and CD73 & $\begin{array}{l}50 \mathrm{mg} / \mathrm{kg} \text { APCP } \\
\text { (antagonist) i.p. days 0-6 }\end{array}$ & $\begin{array}{l}\uparrow \text { Weight loss } \\
\uparrow \text { Histological damage } \\
\uparrow \text { Serum human IL-2 }\end{array}$ & [113] \\
\hline Humanised & $\begin{array}{l}20 \times 10^{6} \text { CD25-depleted } \\
\text { hPBMC + PBS, GMSCs }{ }^{\mathrm{m}}, \\
\text { human fibroblasts or nTregs }{ }^{n} \\
\text { (i.v.) }\end{array}$ & NOD.Cg-Prkdc $c^{\text {scid }}$ & CD39 & $\begin{array}{l}100 \mu \mathrm{M} \mathrm{POM}-1^{\circ} \\
\text { (antagonist) was used to } \\
\text { pretreat GMSCs }\end{array}$ & $\begin{array}{l}\uparrow \text { Mortality } \\
\uparrow \text { Histological damage } \\
\uparrow \text { Serum IL-4, IL-17, IFN- } \gamma \text {, } \\
\text { IL-2 and TNFP }-\alpha .\end{array}$ & [116] \\
\hline
\end{tabular}

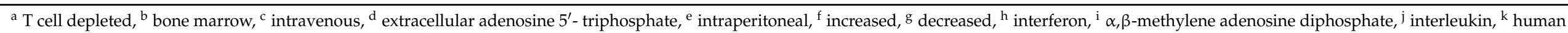
peripheral blood mononuclear cells, ${ }^{1}$ NOD.Cg-Prkdscid Il2rg ${ }^{\text {null }},{ }^{\mathrm{m}}$ gingival mesenchymal stem cells, ${ }^{\mathrm{n}}$ natural regulatory $\mathrm{T}$ cells, ${ }^{\mathrm{o}}$ polyoxotungstate-1, $\mathrm{p}$ tumour necrosis factor. 
Pharmacological blockade of P2X7 reduces GVHD in both allogeneic and humanised mouse models of disease (Table 2). The P2X7 antagonists PPADS (days 0-10), KN62 (days 0-10) or A-438079 (days 0-4) increased survival in an allogeneic mouse model of GVHD $[72,110]$. PPADS treatment also decreased serum IFN- $\gamma$ and tissue inflammation, which coincided with increased Tregs [72]. Similarly, PPADS treatment (days 0-10) reduced histological GVHD and increased human Tregs in a humanised mouse model of GVHD [117]. Treatment with stavudine (from days -1-9) increased survival and decreased serum pro-inflammatory cytokines, including IFN- $\gamma$, in an allogeneic mouse model of GVHD [100]. However, as noted above, the mechanism by which stavudine inhibits P2X7 remains to be fully established. The P2X7 antagonist BBG (twice weekly for 4 weeks) also reduced weight loss, liver inflammation and inflammatory cytokine expression or release, as well as decreasing P2X7 in allogeneic mice with GVHD [114]. BBG (days 0, 2, 4, 6, 8, 10) also reduced serum IFN- $\gamma$ and inflammation in the liver, skin and small intestine in a humanised mouse model of GVHD [118]. Furthermore, daily BBG treatment over this same time period (days 0-10) reduced clinical and histological GVHD, and serum IFN- $\gamma$, and increased the proportions of human Tregs and B cells in a humanised mouse model of GVHD [117]. However, long-term treatment with BBG (thrice weekly until endpoint) only reduced liver inflammation but not serum IFN- $\gamma$ [119]. These differences suggest that timing of P2X7 antagonism may alter disease outcomes in GVHD. Regardless, these four studies with BBG suggest this compound is having a consistent effect on reducing liver GVHD, perhaps indicating that this compound accumulates at higher concentrations in the liver than other tissues and may be acting at the site of tissue damage. 
Table 2. P2X7 blockade in mouse models of graft-versus-host disease.

\begin{tabular}{|c|c|c|c|c|c|c|}
\hline Model & Graft & Host & Target & $\begin{array}{l}\text { Drug Regime (All } \\
\text { Antagonists) }\end{array}$ & Outcomes & Ref. \\
\hline Allogeneic & $\begin{array}{l}5 \times 10^{6} \mathrm{TCD}^{\mathrm{a}} \mathrm{BM}^{\mathrm{b}} \text { cells }+1.6 \\
\times 10^{6}(\mathrm{FVB} / \mathrm{N}) \text { or } 1 \times 10^{6} \\
\mathrm{CD} 4^{+} / \mathrm{CD}^{+}(\mathrm{C} 57 \mathrm{BL} / 6) \\
\left(\text { i.v. }{ }^{\mathrm{c}}\right)\end{array}$ & $\mathrm{BALB} / \mathrm{c}$ & $\mathrm{P} 2 \mathrm{X} 7$ & $\begin{array}{l}10 \mu \mathrm{mol} \text { PPADS }{ }^{\text {d }} \text { i.p. } \\
\text { days } 0-10\end{array}$ & $\begin{array}{l}\uparrow^{\mathrm{f}} \text { Survival } \\
\uparrow \text { Tregs }, \downarrow \text { T cell expansion } \\
\downarrow^{\mathrm{h}} \text { Serum IFN }{ }^{\mathrm{i}}-\gamma \\
\downarrow \text { GVHD severity }\end{array}$ & [72] \\
\hline Allogeneic & $\begin{array}{l}5 \times 10^{6} \mathrm{TCD} \text { BM cells }+1 \times \\
10^{6} \mathrm{CD}^{+} / \mathrm{CD}^{+}(\mathrm{C} 57 \mathrm{BL} / 6) \\
\text { (i.v.) }\end{array}$ & $\mathrm{BALB} / \mathrm{c}$ & $\mathrm{P} 2 \mathrm{X} 7$ & $\begin{array}{l}1 \mu \mathrm{mol} \text { KN62 i.p. days } \\
0-10\end{array}$ & $\uparrow$ Survival & {$[72]$} \\
\hline Allogeneic & $\begin{array}{l}10 \times 10^{6} \mathrm{CD} 25 \text { depleted } \mathrm{T} \\
\text { cells }(\mathrm{C} 57 \mathrm{BL} / 6)(\text { injection } \\
\text { route not disclosed) }\end{array}$ & $\mathrm{BALB} / \mathrm{c}$ & $\mathrm{P} 2 \mathrm{X} 7$ & $\begin{array}{l}80 \mathrm{mg} / \mathrm{kg} \text { A-438079 i.p. } \\
\text { day 0-4 }\end{array}$ & $\uparrow$ Survival & [110] \\
\hline Allogeneic & $\begin{array}{l}10 \times 10^{6} \mathrm{TCD} \text { BM cells }+2.5 \times \\
10^{6} \mathrm{CD}^{+} \mathrm{T} \text { cells }(\mathrm{C} 57 \mathrm{BL} / 6) \\
\text { (injection route not disclosed) }\end{array}$ & $\mathrm{BALB} / \mathrm{c}$ & $\mathrm{P} 2 \mathrm{X} 7$ & $\begin{array}{l}25 \mathrm{mg} / \mathrm{kg} \text { Stavudine }(\mathrm{d} 4 \mathrm{~T}) \\
\text { i.p. twice daily from day } \\
-1 \text { or } 0\end{array}$ & $\begin{array}{l}\uparrow \text { Survival (when started from } \\
\text { day }-1 \text { ) } \\
\downarrow \text { Serum IFN- } \gamma, \mathrm{TNF}_{-}-\alpha \text { and } \\
\mathrm{IL}^{\mathrm{k}}-6 \\
\downarrow \text { Liver inflammation }\end{array}$ & [100] \\
\hline Humanised & $10 \times 10^{6}$ hPBMCs $^{\mathrm{m}}$ (i.p.) & $\mathrm{NSG}^{\mathrm{n}}$ & $\mathrm{P} 2 \mathrm{X} 7$ & $\begin{array}{l}50 \mathrm{mg} / \mathrm{kg} \text { BBG i.p. days } 0 \\
2,4,6,8,10\end{array}$ & $\begin{array}{l}\downarrow \text { Serum IFN- } \gamma \\
\downarrow \text { Liver, skin and small } \\
\text { intestine inflammation }\end{array}$ & [118] \\
\hline Humanised & $10 \times 10^{6}$ hPBMCs (i.p.) & NSG & $\mathrm{P} 2 \mathrm{X} 7$ & $\begin{array}{l}50 \mathrm{mg} / \mathrm{kg} \text { BBG i.p. thrice } \\
\text { weekly until endpoint }\end{array}$ & $\downarrow$ Liver inflammation & [119] \\
\hline Humanised & $10 \times 10^{6}$ hPBMCs (i.p.) & NSG & $\mathrm{P} 2 \mathrm{X} 7$ & $\begin{array}{l}50 \mathrm{mg} / \mathrm{kg} \text { BBG i.p. days } \\
0-10\end{array}$ & $\begin{array}{l}\downarrow \text { Clinical disease } \\
\downarrow \text { Liver and skin inflammation } \\
\downarrow \text { Serum IFN- } \gamma \\
\uparrow \text { Tregs and B cells }\end{array}$ & [117] \\
\hline Humanised & $10 \times 10^{6}$ hPBMCs (i.p.) & NSG & $\mathrm{P} 2 \mathrm{X} 7$ & $\begin{array}{l}300 \mathrm{mg} / \mathrm{kg} \text { PPADS i.p. } \\
\text { days } 0-10\end{array}$ & $\uparrow$ Tregs & [117] \\
\hline
\end{tabular}

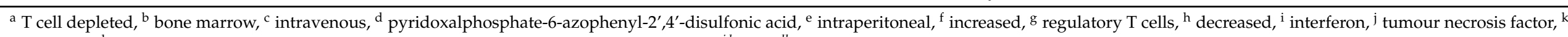
interleukin, ${ }^{1}$ Brilliant blue $\mathrm{G},{ }^{\mathrm{m}}$ human peripheral blood mononuclear cells, ${ }^{\mathrm{n}}$ NOD.Cg-Prkd ${ }^{\text {scid }} I l 2 r \mathrm{r}^{\text {null }}$. 
Genetic studies in mice confirm that P2X7 is involved in GVHD progression and provide further insight to the potential mechanism of this receptor in this disease. Comparisons of $P 2 r x 7^{-/-}$and $w t$ mice as either the source of donor cells or recipient mice indicated that host, but not donor, P2X7 contributes to GVHD progression in an allogeneic mouse model [72]. Furthermore, bone marrow chimeras in $P 2 r x 7^{-/-}$or $w t$ mice demonstrated that P2X7 in the host haematopoietic system, but not non-haematopoietic tissues, influences GVHD in allogeneic mice [72]. Finally, bone marrow chimeras with a host $P 2 r x 7^{-1-}$ haematopoietic system including $P 2 r x 7^{-/-}$DCs had reduced disease compared to mice with a host $P 2 r x 7^{-/-}$haematopoietic system but $w t \mathrm{DCs}$, indicating that P2X7 on host DCs is contributing to GVHD development [72].

The importance of host P2X7 in GVHD is supported by studies of human P2RX7 SNPs in mice and humans. NSG mice injected with PBMCs from donors with either a LOF or gain-of-function (GOF) P2RX7 haplotype display similar GVHD development [120]. Likewise, donor $P 2 R X 7$ genotype did not influence rates or severity of GVHD in alloHSCT recipients [78]. Conversely, the LOF rs3751143 SNP in the host was associated with improved survival, however, other LOF SNPs in the host were not associated with reduced GVHD and the LOF rs1653624 SNP was associated with increased GVHD [78].

The above studies indicate that host P2X7 is important in GVHD development however, they do not exclude the potential contribution of donor P2X7 influencing disease. P2X7 activation can promote the activation and proliferation of $\mathrm{CD} 4^{+} \mathrm{T}$ cells in an IL-2 dependant manner [86] and can help promote the metabolic fitness, maintenance and survival of memory $\mathrm{CD}^{+} \mathrm{T}$ cells $[121,122]$, thus the possibility remains that P2X7 may contribute to the activation and survival of donor effector T cells in GVHD. Additionally, P2X7 activation can inhibit the suppressive action and stability of Tregs, promoting their conversion to $\mathrm{T}$ helper 17 (Th17) cells [123]. This may potentially cause P2X7 activation to be a "double edged sword" in GVHD progression, both impairing Tregs and promoting pathogenic Th17 cells. Consistent with this notion is that PPADS and/or BBG increase donor Treg survival in allogeneic [72] and humanised [117] mouse models of GVHD. Finally, studies of donor myeloid derived suppressor cells (MDSCs) in an allogeneic mouse model of GVHD provide indirect evidence for donor P2X7 in promoting this disease. Transplantation of donor MDSCs can impair GVHD development [124], however P2X7 activation of these cells prior to transplant limits their capacity to reduce GVHD in vivo [110]. Thus, this study suggests P2X7 on MDSCs present in the donor graft may impair the action of these suppressor cells to help promote GVHD in allo-HSCT recipients.

In conclusion, increases in extracellular ATP during GVHD lead to P2X7 activation on host APCs, which promotes cytokine release and donor T cell activation, with additional P2X7 activation on T cells directly promoting their proliferation and survival. Further, activation of P2X7 on donor Tregs and MDSCs may lead to reduced suppression of effector cells. Therefore, P2X7 remains a potential clinical target for treatment of GVHD.

\section{8. $\mathrm{P}_{2} \mathrm{Y}_{2}$ and $\mathrm{P}_{2} \mathrm{Y}_{12}$ Receptor Signalling in GVHD}

In addition to $\mathrm{P} 2 \mathrm{X} 7$ a small number of studies implicate $\mathrm{P} 2 \mathrm{Y}_{2}$, and to a lesser extent $\mathrm{P} \mathrm{Y}_{12}$, in the pathogenesis of GVHD [26,115]. P2 $\mathrm{Y}_{2}$ expressing cells, mostly myeloid cells, are increased in the intestinal tract of allo-HSCT recipients with GVHD, with the presence of $\mathrm{P}_{2} \mathrm{Y}_{2}$-expressing cells associated with increased intestinal GVHD severity [125]. Notably, $P 2 r y 2^{-/-}$recipient mice, but not $P 2 r y 2^{-/-}$donor cells, displayed reduced clinical GVHD and increased survival, which corresponded to reduced histological GVHD, serum IL-6 concentrations and other inflammatory molecules compared to $w t$ recipient mice [125]. Using bone marrow chimeras, a role of $\mathrm{P}_{2} \mathrm{Y}_{2}$ in GVHD was found to be more dependent on the host haematopoietic system than the non-haematopoietic system. The role of P2Y 2 in the host haematopoietic system was due to its expression on inflammatory monocytes but not DCs [125]. Whilst the role of $\mathrm{P}_{2} \mathrm{Y}_{2}$ in the host non-haematopoietic system was hypothesised to be due to reduced $\mathrm{P}_{2} \mathrm{Y}_{2}$-mediated apoptosis of enterocytes (intestinal cells), 
with apoptosis of these cells reduced in $P 2 r y 2^{-/-}$host mice compared to $w t$ host mice following allo-HSCT [125].

$\mathrm{P}_{2} \mathrm{Y}_{2}$ may also contribute to GVHD progression by mediating the migration of DCs to sites of inflammation and ATP release [115], but as indicated above this is not an absolute

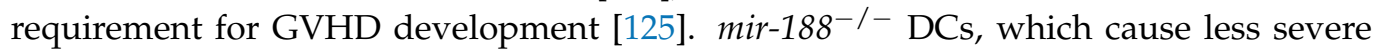
GVHD in an allogeneic mouse model, display reduced amounts of P2ry2 and P2ry12 compared to $w t$ DCs [115]. Whilst mir-188 ${ }^{-/-}, P 2 r y 2^{-/-}$and $P 2 r y 12^{-/-}$DCs all display impaired in vitro migration compared to $w t$ DCs [115], evidence supporting a role for $\mathrm{P}_{2} \mathrm{Y}_{2}$ or $\mathrm{P}_{2} \mathrm{Y}_{12}$ in DC migration in GVHD in vivo is lacking.

Conversely, $\mathrm{P}_{2} \mathrm{Y}_{2}$ can limit GVHD progression by mediating migration of Tregs to sites of inflammation and ATP release. Co-injection of donor conventional T cells with donor P2ry $2^{-1-}$ Tregs abrogates protection against GVHD afforded by the co-injection of donor conventional $\mathrm{T}$ cells with donor $w t$ Tregs in an allogeneic mouse model [73]. Notably the addition of either donor $w t$ or $P 2 r y 2^{-1-}$ Tregs reduced the expansion of donor conventional $\mathrm{T}$ cells to a similar extent in vivo, suggesting that the role of $\mathrm{P}_{2} \mathrm{Y}_{2}$ may be in directing Tregs to GVHD tissues to reduce inflammation at these sites. Thus, given the opposing roles of $\mathrm{P}_{2} \mathrm{Y}_{2}$ in DCs and Tregs in GVHD, systemic targeting of this receptor may be limited. To the best of our knowledge, no studies have reported the use of $\mathrm{P} 2 \mathrm{Y}_{2}$ or $\mathrm{P} 2 \mathrm{Y}_{12}$ antagonists to prevent GVHD in vivo.

A further role for $\mathrm{P}_{2} \mathrm{Y}_{2}$ in GVHD is in relation to dry eye disease, which is often associated with GVHD in allo-HSCT recipients [126]. P2 $\mathrm{Y}_{2}$ activation is well known to induce the shedding of various cell surface molecules including tumour necrosis factor (TNF) receptor 1 (TNFR1) [127]. In the context of GVHD, soluble TNFR1 is increased in the tear fluid of patients compared to that of healthy controls, where it is thought to have a role in reducing inflammation on the eye surface by impairing TNF $\alpha$-induced intracellular signalling [128]. Moreover, addition of the $\mathrm{P}_{2} \mathrm{Y}_{2}$ agonist diquafosol, an effective treatment of dry eye disease [129], increases the concentration of soluble TNFR1 in the tear fluid of people with GVHD [128]. Collectively, this suggests local activation of $\mathrm{P}_{2} \mathrm{Y}_{2}$ within the eye may limit the inflammation associated with dry eye disease in people with GVHD.

\section{Adenosine Receptor Signalling in GVHD}

As introduced above, ATP released at the sites of damage in allo-HSCT recipients promotes inflammation, but its degradation by apyrase can prevent GVHD [72] suggesting a beneficial role for the ecto-nucleotidases CD39 and CD73. In allogeneic mouse models of GVHD, pharmacological blockade of CD73 with APCP (days 0-6) [111] or APCP (twice weekly) [112] increased splenic $\mathrm{CD} 4^{+}$and $\mathrm{CD} 8^{+} \mathrm{T}$ cell numbers and serum IFN- $\gamma$ and IL-6 concentrations and mouse mortality. As noted above, APCP also blocks CD39 [103], therefore a role for CD39 in this process cannot be excluded. However, genetic deficiency of CD73 in the donor or recipient also increased splenic $\mathrm{CD} 4^{+}$and $\mathrm{CD} 8^{+} \mathrm{T}$ cell numbers, serum IFN $\gamma$ and IL- 6 concentrations, histological damage in target organs, and mortality in allogeneic mouse models of GVHD [111,112] supporting a role for CD73 in limiting GVHD progression. Finally, a recent study demonstrated that murine CD150 ${ }^{\text {hi }}$ Treg cells exhibit significantly higher Entpd1 (CD39) and Nt5e (CD73) mRNA expression than CD150- Tregs and mediate their suppressive effect through adenosine production, reducing histological GVHD and mortality, and promoting HSC expansion in an allogeneic mouse model of GVHD [130].

Further evidence for a role of CD39/CD73 in GVHD arises from studies using humanised mice. Transfer of human gingiva-derived mesenchymal stem cells into humanised NOD.Cg-Prkd $c^{s c i d}$ mice reduced histological damage, cytokine production by human $\mathrm{T}$ cells, and mouse mortality, however these effects were lost when these cells were incubated with the CD39 antagonist POM-1 prior to transplantation [116]. Blockade of CD39 and CD73 using the antagonist APCP (days 0-6), in a humanised NSG mouse model, increased weight loss, liver GVHD and serum human IL-2 concentrations [113]. Finally, mice injected with PBMCs from human donors with the intronic rs10748643 SNP in the ENTPD1 gene 
(encoding CD39), which results in higher proportions of CD39+ Tregs and greater suppressive capacity [131], had worsened GVHD compared to NSG mice injected with PBMCs from donors without this SNP [132].

Adenosine produced by CD39/CD73 mediates its effects largely through activation of $\mathrm{A}_{2 \mathrm{~A}}$ to limit GVHD progression. The role of $\mathrm{A}_{2 \mathrm{~A}}$ in GVHD was originally shown in allogeneic mouse models of this disease (Table 3). The non-selective adenosine receptor antagonist caffeine (days 0-6, and 3-5 times a week onwards) worsened mortality [111]. Moreover, the $\mathrm{A}_{2 \mathrm{~A}}$ antagonist SCH58261, but not the $\mathrm{A}_{2 \mathrm{~B}}$ antagonist MRS1754 (days -2-12) increased serum TNF $\alpha$, IFN- $\gamma$ and IL-6, CD4 ${ }^{+}$and CD8 ${ }^{+}$T cell numbers, and worsened mortality [112]. Additionally, genetic deficiency of $A_{2 A}$ in the host increased $\mathrm{CD}^{+}$and $\mathrm{CD} 8^{+} \mathrm{T}$ cell numbers $[111,112]$, but the effect on mortality was not reported in either study. Supporting the role of $A_{2 A}$ activation in limiting GVHD progression, treatment with the $\mathrm{A}_{2 \mathrm{~A}}$ agonist ATL-146e increased serum IL-10, and reduced serum IFN- $\gamma$ and IL-6 [133]. Furthermore, ATL-146e reduced activated splenic CD4 ${ }^{+}$and $\mathrm{CD}^{+} \mathrm{T}$ cell numbers, decreased $\mathrm{T}$ cell infiltration into GVHD tissue, and reduced both weight loss and mortality in an allogeneic mouse model of GVHD. ATL-146e, as well as the other $\mathrm{A}_{2 \mathrm{~A}}$ agonists ATL-370 and ATL-1223, also increased donor derived Treg cells in both the skin and colon in this same model [134]. 
Table 3. Adenosine receptor blockade or activation in mouse models of GVHD.

\begin{tabular}{|c|c|c|c|c|c|c|}
\hline Model & Graft & Host & Target & Drug Regime & Outcomes & Ref. \\
\hline Allogeneic & $\begin{array}{l}5 \times 10^{6} \mathrm{BM}^{\mathrm{a}} \text { cells and } 2 \times 10^{5} \\
\mathrm{CD} 4^{+} / \mathrm{CD}^{+} \text {splenic } \mathrm{T} \text { cells } \\
\left(\text { (i.v. }^{\mathrm{b}} \text { ) }\right.\end{array}$ & C57BL/ 6 & Adenosine receptors & $\begin{array}{l}10 \mathrm{mg} / \mathrm{kg} \text { Caffeine } \\
\text { (antagonist) i.p. }{ }^{\mathrm{C}} \text { days 0-6 } \\
\text { then 3-5 times a week }\end{array}$ & $\uparrow^{\mathrm{d}}$ Mortality & [111] \\
\hline Allogeneic & $\begin{array}{l}5 \times 10^{6} \text { BALB } / \text { c splenocytes } \\
\pm \text { BM cells or splenocytes (i.v.) }\end{array}$ & C57BL/6 & $\mathrm{A}_{2 \mathrm{~A}}$ & $\begin{array}{l}2 \mathrm{mg} / \mathrm{kg} \mathrm{SCH} 58261 \\
\text { (antagonist) i.p. days } \\
-2-12\end{array}$ & $\begin{array}{l}\uparrow \text { Mortality } \\
\uparrow \text { Splenic CD4 }{ }^{+} \text {and } \mathrm{CD}^{+} \mathrm{T} \\
\text { cells } \\
\uparrow \text { Serum IFN }{ }^{\mathrm{e}}-\gamma, \mathrm{TNF}^{\mathrm{f}}-\alpha \text { and } \\
\mathrm{IL}^{-}-6\end{array}$ & [112] \\
\hline Allogeneic & $\begin{array}{l}5 \times 10^{6} \text { BALB } / \mathrm{c} \text { splenocytes } \\
\pm \mathrm{BM} \text { cells or splenocytes (i.v.) }\end{array}$ & C57BL/ 6 & $\mathrm{~A}_{2 \mathrm{~B}}$ & $\begin{array}{l}2 \mathrm{mg} / \mathrm{kg} \text { MRS1754 } \\
\text { (antagonist) i.p. days } \\
-2-12\end{array}$ & No differences & [112] \\
\hline Allogeneic & $\begin{array}{l}10 \times 10^{6} \text { C57BL } / 6 \text { splenocytes } \\
\pm 10 \times 10^{6} \text { T cells (i.v.) }\end{array}$ & $\mathrm{B} 6 \mathrm{D} 2 \mathrm{~F} 1 / \mathrm{J}$ & $\mathrm{A}_{2 \mathrm{~A}}$ & $\begin{array}{l}10 \mathrm{ng} / \mathrm{kg} \text { ATL-146e } \\
\text { (agonist) s.c. days 0-14 }\end{array}$ & $\begin{array}{l}\uparrow \text { Survival } \\
\uparrow \text { Serum IL-10 } \\
\downarrow \text { h Splenic CD4 }{ }^{+} \text {and CD8 }{ }^{+} \mathrm{T} \\
\text { cells } \\
\downarrow \mathrm{T} \text { cell infiltration into target } \\
\text { organs } \\
\downarrow \text { Serum IFN- } \gamma \text { and IL-6 }\end{array}$ & [133] \\
\hline Humanised & $\begin{array}{l}5 \times 10^{6} \text { human Th } 1^{\mathrm{i}} \text { cells and } \\
3 \times 10^{6} \text { human monocytes } \\
\text { (i.p.) }\end{array}$ & NSG & $\mathrm{A}_{2 \mathrm{~A}}$ & $\begin{array}{l}1.5 \mathrm{mg} / \mathrm{kg} \text { ZM241385 } \\
\text { (antagonist) i.p. daily from } \\
\text { disease onset until } \\
\text { endpoint }\end{array}$ & $\begin{array}{l}\uparrow \text { Mortality } \\
\uparrow \text { Histological damage } \\
\uparrow \text { IFN- } \gamma \text { and TNF- } \alpha \text { producing } \\
\text { cells }\end{array}$ & [135] \\
\hline Humanised & $10 \times 10^{6}$ hPBMCs $^{\mathrm{k}}$ (i.p.) & NSG & Adenosine receptors & $\begin{array}{l}10 \mathrm{mg} / \mathrm{kg} \text { Caffeine } \\
\text { (antagonist) i.p. days 0-14 }\end{array}$ & No differences & [113] \\
\hline Humanised & $10 \times 10^{6}$ hPBMCs (i.p.) & NSG & $\mathrm{A}_{2 \mathrm{~A}}$ & $\begin{array}{l}0.1 \mathrm{mg} / \mathrm{kg} \text { CGS } 21680 \\
\text { (agonist) i.p. day }-2-11\end{array}$ & $\begin{array}{l}\uparrow \text { Weight loss } \\
\uparrow \text { Serum human IL-6 } \\
\downarrow \text { Histological damage } \\
\downarrow \text { Serum human TNF- } \alpha\end{array}$ & [136] \\
\hline
\end{tabular}

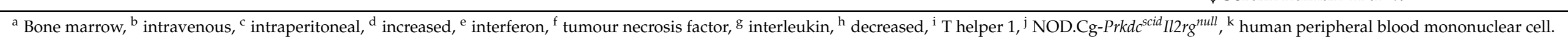


Further evidence for the role of $A_{2 A}$ in GVHD has been found using humanised mouse models. Human bone marrow derived mesenchymal stromal cells reduced IFN- $\gamma-$ and TNF- $\alpha$-producing leukocytes and reversed clinical disease in a humanised mouse model [135]. However, these beneficial effects were abrogated by the $\mathrm{A}_{2 \mathrm{~A}}$ antagonist ZM241385 (from GVHD onset until endpoint), which prevented human T cell suppression, worsened disease, and reduced survival [135]. Contrary to allogeneic mouse models, injection of caffeine (days 0-14) did not impact weight loss, clinical score, survival, histology or serum cytokine concentrations in a humanised mouse model [113]. While injection of the $\mathrm{A}_{2 \mathrm{~A}}$ agonist CGS21680 (days -2-11) had confounding effects in these mice, appearing to worsen disease by increasing weight loss and serum human IL-6 concentrations, but also potentially alleviating disease severity by reducing leukocyte infiltration into the liver and serum human $\mathrm{TNF} \alpha$ concentrations [136].

\section{Conclusions}

The current review has briefly described how allo-HSCT is used in the treatment of haematological malignancies, reconstituting the immune system and providing a GVT effect. However, allo-HSCT also leads to GVHD, a severe immunological response against various tissues in the transplant recipient. Purinergic signalling is a modulator of HSC homeostasis, differentiation, mobilisation and death, and as such, plays a role in alloHSCT. Furthermore, current evidence suggests that the purinergic system plays a variety of roles in GVHD progression (Figure 2) and as such, presents a viable target for developing new therapies. $\mathrm{P} 2 \mathrm{X} 7$ and $\mathrm{A}_{2 \mathrm{~A}}$ have pro- and anti-inflammatory effects, respectively, during GVHD, whilst CD39/CD73 exerts anti-inflammatory effects through the degradation of extracellular ATP and generation of extracellular adenosine. $\mathrm{P}_{2} \mathrm{Y}_{2}$ receptors play opposing roles on different cell types, and thus, may not be well-suited as a therapeutic target. Blockade of $\mathrm{P} 2 \mathrm{X} 7$ or activation of $\mathrm{A}_{2 \mathrm{~A}}$ present promising therapies for future GVHD treatment, but further studies in both allogeneic and humanised mouse models of this disease, as well as patients with GVHD, are required before these molecules can be targeted clinically.

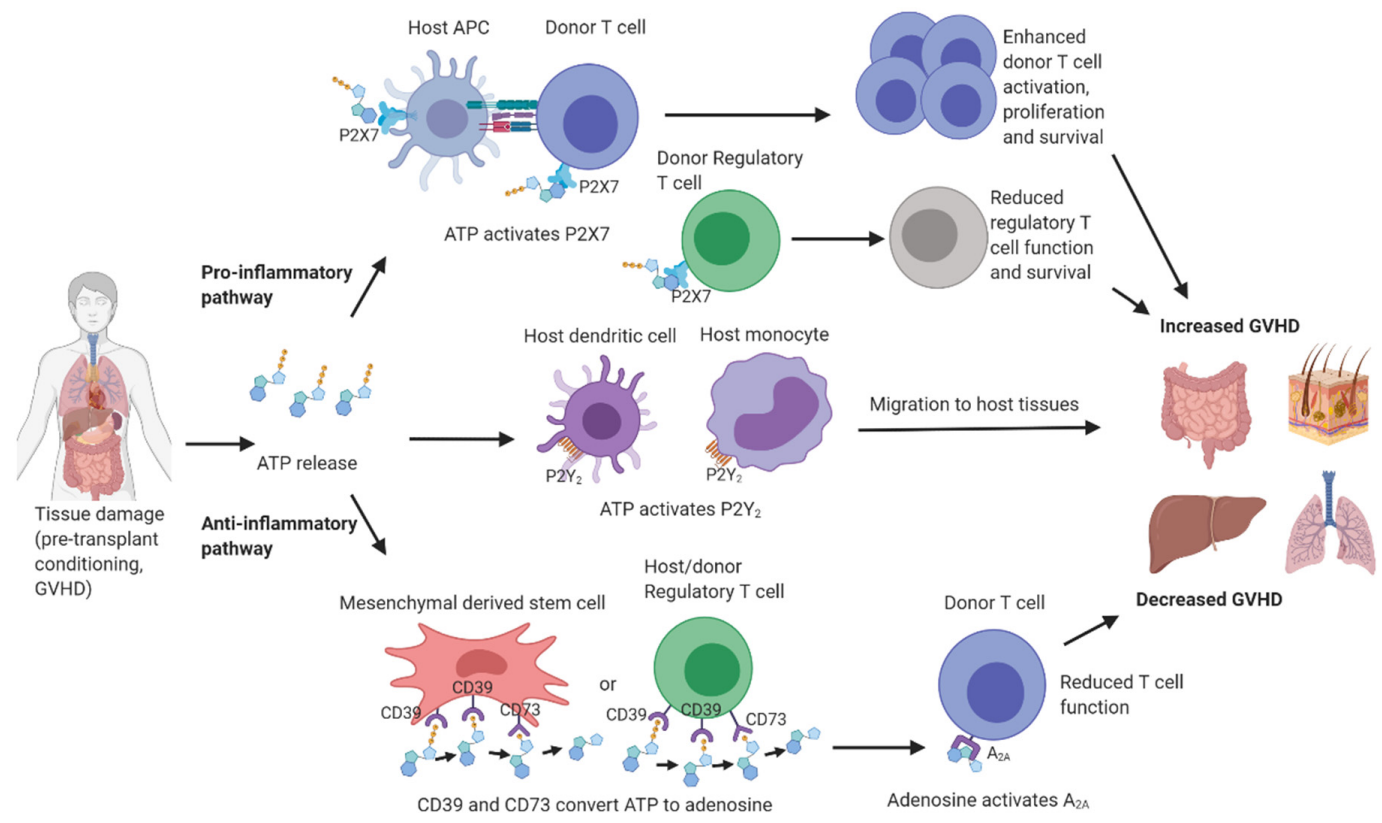

Figure 2. The role of the purinergic signalling molecules during graft-versus-host disease. Tissue damage from pre-transplant conditioning or GVHD results in adenosine $5^{\prime}$-triphosphate (ATP) release. This ATP activates P2X7 on host antigen presenting cells (APCs) and donor T cells leading to donor T cell enhanced activation, proliferation and survival. ATP can also activate P2X7 on regulatory T cells, reducing their function and survival. P2X7 activation on myeloid derived suppressor cells can reduce their suppressive capacity (not shown). Combined these pathways result in worsened GVHD. ATP can also activate $\mathrm{P}_{2} \mathrm{Y}_{2}$ on host dendritic cells and monocytes initiating the migration of these cells to inflamed tissues. Alternatively, ATP can be converted to ADP then AMP by CD39 present on mesenchymal stem cells or regulatory T cells. CD73 receptors on these same cells, or other cells (not shown) convert AMP to adenosine which activates $A_{2 A}$ receptors on donor T cells, reducing T cell function. This conversion of ATP to adenosine results in reduced GVHD. Created with BioRender.com. 
Author Contributions: All authors contributed to the initial writing and subsequent editing of this manuscript. P.C. assembled the final version including tables and created the figures. All authors have read and agreed to the published version of the manuscript.

Funding: P.C.: S.R.A., K.B. are supported through Australian Government Research Training Program Scholarships. N.J.G. is supported by Motor Neurone Disease Research Australia Marisa Aguis Post-Doctoral Fellowship. S.J.F is supported by a Nepean Medical Research Foundation Project Grant. D.W. is supported by Cancer Council NSW. R.S. received donations from John and Betsie van Schelven (to Bone Marrow Failure Research, Illawarra Health and Medical Research Institute). D.W. and R.S. received additional support from Molecular Horizons (University of Wollongong).

Conflicts of Interest: All authors declare they have no conflict of interest.

\begin{abstract}
Abbreviation
$\alpha: \beta$-methylene ADP (APCP), adenosine $5^{\prime}$-diphosphate (ADP), adenosine 5'-monophosphate (AMP), adenosine $5^{\prime}$-triphosphate (ATP), Allogeneic haematopoietic stem cell transplantation (allo-HSCT), antigen presenting cell (APC), ATP diphosphohydrolase (ATPDase), Brilliant Blue G (BBG), dendritic cell (DC), ecto-nucleoside triphosphate diphosphohydrolase (E-NTPDase), gain-of-function (GOF), graft-versus-host disease (GVHD), graft-versus-tumour (GVT), granulocyte-colony stimulating factor (G-CSF), haematopoietic stem cell (HSC), human leukocyte antigen (HLA), interferon (IFN), interleukin (IL), loss-of-function (LOF), major histocompatibility complex (MHC), myeloid derived suppressor cell (MDSC), natural killer (NK), NOD.Cg-Prkdcscid Il2rgtm1Sug (NOG), NOD.Cg-

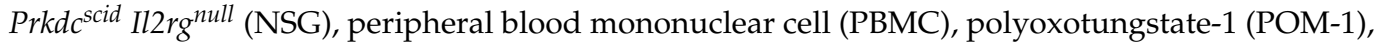
pyridoxalphosphate-6-azophenyl-2', $4^{\prime}$-disulfonic acid (PPADS), regulatory T cell (Treg), single nucleotide polymorphism (SNP), T helper 17 (Th17), tumour necrosis factor (TNF), tumour necrosis factor receptor 1 (TNFR1), uridine $5^{\prime}$-triphosphate (UTP), wild-type (wt).
\end{abstract}

\title{
References
}

1. Siegel, R.L.; Miller, K.D.; Jemal, A. Cancer statistics. CA Cancer J. Clin. 2016, 66, 7-30. [CrossRef]

2. Appelbaum, F.R. Hematopoietic-cell transplantation. N. Engl. J. Med. 2007, 357, 1472-1475. [CrossRef]

3. Zeiser, R.; Blazar, B.R. Acute graft-versus-host disease-Biologic process, prevention, and therapy. N. Engl. J. Med. 2017, 377, 2167-2179. [CrossRef]

4. Truitt, R.L.; Atasoylu, A.A. Contribution of CD4+ and CD8+ T cells to graft-versus-host disease and graft-versus-leukemia re-activity after transplantation of MHC-compatible bone marrow. Bone Marrow Transpl. 1991, 8, 51-58.

5. Sprent, J.; Schaefer, M.; Gao, E.K.; Korngold, R. Role of T cell subsets in lethal graft-versus-host disease (GVHD) directed to class I versus class II H-2 differences. I. L3T4+ cells can either augment or retard GVHD elicited by Lyt-2+ cells in class I different hosts. J. Exp. Med. 1988, 167, 556-569. [CrossRef] [PubMed]

6. Namdaroglu, S.; Kaya, A.H.; Batgi, H.; Kayikci, O.; Dal, M.S.; Iskender, D.; Cakar, M.K.; Tekgunduz, E.; Altuntas, F. Impacts of post-transplantation cyclophosphamide treatment after allogeneic hematopoietic stem cell transplantation in acute myeloid leukemia. Sci. Rep. 2019, 9, 1-6. [CrossRef] [PubMed]

7. Burnstock, G. Purine and purinergic receptors. Brain Neurosci. Adv. 2018, 2. [CrossRef]

8. Bach, F.H.; Albertini, R.J.; Joo, P.; Anderson, J.L.; Bortin, M.M. Bone-marrow transplantation in a patient with the Wiskott-Aldrich syndrome. Lancet 1968, 2, 1364-1366. [CrossRef]

9. Thomas, E.D.; Storb, R.; Fefer, A.; Slichter, S.; Bryant, J.; Buckner, C.D.; Neiman, P.; Clift, R.; Funk, D.; Lerner, K. A plastic anaemia treated by marrow transplantation. Lancet 1972, 299, 284-289. [CrossRef]

10. Lapidot, T.; Dar, A.; Kollet, O. How do stem cells find their way home? Blood 2005, 106, 1901-1910. [CrossRef] [PubMed]

11. Bacigalupo, A.; Ballen, K.; Rizzo, D.; Giralt, S.; Lazarus, H.; Ho, V.; Apperley, J.; Slavin, S.; Pasquini, M.; Sandmaier, B.M.; et al. Defining the intensity of conditioning regimens: Working definitions. Biol. Blood Marrow Transplant. 2009, 15, 1628-1633. [CrossRef]

12. Gyurkocza, B.; Sandmaier, B.M. Conditioning regimens for hematopoietic cell transplantation: One size does not fit all. Blood 2014, 124, 344-353. [CrossRef] [PubMed]

13. Copelan, E.A. Hematopoietic stem-cell transplantation. N. Engl. J. Med. 2006, 354, 1813-1826. [CrossRef]

14. Bishop, M.R.; Tarantolo, S.R.; Geller, R.B.; Lynch, J.C.; Bierman, P.J.; Pavletic, Z.S.; Vose, J.M.; Kruse, S.; Dix, S.P.; Morris, M.E.; et al. A randomized, double-blind trial of filgrastim (granulocyte colony-stimulating factor) versus placebo following allogeneic blood stem cell transplantation. Blood 2000, 96, 80-85. [CrossRef]

15. Barnes, D.W.H.; Loutit, J.F. Treatment of murine leukaemia with X-rays and homologous bone marrow. Br. J. Haematol. 1957, 3, 241-252. [CrossRef] 
16. Liang, Y.; Liu, C.; Djeu, J.Y.; Zhong, B.; Peters, T.; Scharffetter-Kochanek, K.; Anasetti, C.; Yu, X.-Z. $\beta 2$ integrins separate graft-versus-host disease and graft-versus-leukemia effects. Blood 2008, 111, 954-962. [CrossRef] [PubMed]

17. Ni, X.; Song, Q.; Cassady, K.; Deng, R.; Jin, H.; Zhang, M.; Dong, H.; Forman, S.; Martin, P.J.; Chen, Y.-Z.; et al. PD-L1 interacts with CD80 to regulate graft-versus-leukemia activity of donor CD8+ T cells. J. Clin. Investig. 2017, 127, 1960-1977. [CrossRef] [PubMed]

18. Ritacco, C.; Ehx, G.; Canti, L.; Dubois, S.; Vandenhove, B.; Servais, S.; Beguin, Y.; Humblet-Baron, S.; Baron, F. Ptcy prevents xenogeneic gvhd without abrogating gvl effects. Biol. Blood Marrow Transplant. 2020, 26, S168. [CrossRef]

19. Delens, L.; Ehx, G.; Somja, J.; Vrancken, L.; Belle, L.; Seidel, L.; Grégoire, C.; Fransolet, G.; Ritacco, C.; Hannon, M.; et al. In vitro Th17-polarized human CD4+ T cells exacerbate xenogeneic graft-versus-host disease. Biol. Blood Marrow Transplant. 2019, 25, 204-215. [CrossRef]

20. Ehx, G.; Fransolet, G.; De Leval, L.; D’Hondt, S.; Lucas, S.; Hannon, M.; Delens, L.; Dubois, S.; Drion, P.; Beguin, Y.; et al. Azacytidine prevents experimental xenogeneic graft-versus-host disease without abrogating graft-versus-leukemia effects. OncoImmunology 2017, 6, e1314425. [CrossRef]

21. Zeng, K.; Ma, H.; Popat, U.; Nieto, Y.; Ciurea, S.O.; Olson, A.L.; Lyu, M.-A.; Huang, M.; Nishimoto, M.; Qazilbash, M.H.; et al. Allogeneic cord blood regulatory t cells can prevent graft vs. host disease and preserve graft vs leukemia effect: Update on phase I/II clinical trial. Blood 2019, 134, 4547. [CrossRef]

22. Versluis, J.; Kalin, B.; Zeijlemaker, W.; Passweg, J.; Graux, C.; Manz, M.G.; Vekemans, M.-C.; Biemond, B.J.; Legdeur, M.-C.J.; Kooy, M.V.M.; et al. Graft-Versus-leukemia effect of allogeneic stem-cell transplantation and minimal residual disease in patients with acute myeloid leukemia in first complete remission. JCO Precis. Oncol. 2017, 1-13. [CrossRef]

23. Ferrara, J.L.; Levine, J.; Reddy, P.; Holler, E. Graft-versus-host disease. Lancet 2009, 373, 1550-1561. [CrossRef]

24. Saber, W.; Opie, S.; Rizzo, J.D.; Zhang, M.-J.; Horowitz, M.M.; Schriber, J. Outcomes after matched unrelated donor versus identical sibling hematopoietic cell transplantation in adults with acute myelogenous leukemia. Blood 2012, 119, 3908-3916. [CrossRef]

25. Lee, S.J.; Klein, J.P.; Barrett, A.J.; Ringden, O.; Antin, J.H.; Cahn, J.-Y.; Carabasi, M.H.; Gale, R.P.; Giralt, S.; Hale, G.A.; et al. Severity of chronic graft-versus-host disease: Association with treatment-related mortality and relapse. Blood 2002, 100, 406-414. [CrossRef] [PubMed]

26. Apostolova, P.; Zeiser, R. The Role of purine metabolites as DAMPs in acute graft-versus-host disease. Front. Immunol. 2016, 7, 439. [CrossRef]

27. Mosmann, T.R.; Cherwinski, H.; Bond, M.W.; Giedlin, M.A.; Coffman, R.L. Two types of murine helper T cell clone. I. Definition according to profiles of lymphokine activities and secreted proteins. J. Immunol. 1986, 136, 2348-2357. [PubMed]

28. Park, H.; Li, Z.; Yang, X.O.; Chang, S.H.; Nurieva, R.; Wang, Y.-H.; Wang, Y.; Hood, L.; Zhu, Z.; Tian, Q.; et al. A distinct lineage of CD4 T cells regulates tissue inflammation by producing interleukin. Nat. Immunol. 2005, 6, 1133-1141. [CrossRef]

29. Schwab, L.; Goroncy, L.; Palaniyandi, S.; Gautam, S.; Triantafyllopoulou, A.; Mócsai, A.; Reichardt, W.; Karlsson, F.J.; Radhakrishnan, S.V.; Hanke, K.; et al. Neutrophil granulocytes recruited upon translocation of intestinal bacteria enhance graft-versus-host disease via tissue damage. Nat. Med. 2014, 20, 648-654. [CrossRef]

30. Hülsdünker, J.; Ottmüller, K.J.; Neeff, H.P.; Koyama, M.; Gao, Z.; Thomas, O.S.; Follo, M.; Al-Ahmad, A.; Prinz, G.; Duquesne, S.; et al. Neutrophils provide cellular communication between ileum and mesenteric lymph nodes at graft-versus-host disease onset. Blood 2018, 131, 1858-1869. [CrossRef]

31. Hong, Y.-Q.; Wan, B.; Li, X.-F. Macrophage regulation of graft-vs-host disease. World J. Clin. Cases 2020, 8, 1793-1805. [CrossRef] [PubMed]

32. Di Ianni, M.; Falzetti, F.; Carotti, A.; Terenzi, A.; Castellino, F.; Bonifacio, E.; Del Papa, B.; Zei, T.; Ostini, R.I.; Cecchini, D.; et al. Tregs prevent GVHD and promote immune reconstitution in HLA-haploidentical transplantation. Blood 2011, 117, 3921-3928. [CrossRef]

33. Ruggeri, L.; Di Ianni, M.; Urbani, E.; Mancusi, A.; Falzetti, F.; Carotti, A.; Terenzi, A.; Massei, M.S.; Amico, L.; Zei, T.; et al. Tregs suppress GvHD at the periphery and unleash the Gvl effect in the bone marrow. Blood 2014, 124, 842. [CrossRef]

34. Tanaka, M.; Kobayashi, S.; Numata, A.; Tachibana, T.; Takasaki, H.; Maruta, A.; Ishigatsubo, Y.; Kanamori, H. The impact of the dose of natural killer cells in the graft on severe acute graft-versus-host disease after unrelated bone marrow transplantation. Leuk. Res. 2012, 36, 699-703. [CrossRef]

35. Kim, S.Y.; Lee, H.; Han, M.-S.; Shim, H.; Eom, H.-S.; Park, B.; Kong, S.-Y. Post-transplantation natural killer cell count: A predictor of acute graft-versus-host disease and survival outcomes after allogeneic hematopoietic stem cell transplantation. Clin. Lymphoma Myeloma Leuk. 2016, 16, 527-535.e2. [CrossRef]

36. Xun, C.; Brown, S.A.; Jennings, C.D.; Henslee-Downey, P.J.; Thompson, J.S. Acute graft-versus-host-like disease induced by transplantation of human activated natural killer cells into SCID mice. Transplantation 1993, 56, 409-416. [CrossRef]

37. Cooley, S.; McCullar, V.; Wangen, R.; Bergemann, T.; Spellman, S.; Weisdorf, D.J.; Miller, J.S. KIR reconstitution is altered by T cells in the graft and correlates with clinical outcomes after unrelated donor transplantation. Blood 2005, 106, 4370-4376. [CrossRef]

38. Olson, J.A.; Leveson-Gower, D.B.; Gill, S.; Baker, J.; Beilhack, A.; Negrin, R.S. NK cells mediate reduction of GVHD by inhibiting activated, alloreactive T cells while retaining GVT effects. Blood 2010, 115, 4293-4301. [CrossRef] [PubMed]

39. Schroeder, M.A.; DiPersio, J.F. Mouse models of graft-versus-host disease: Advances and limitations. Dis. Model. Mech. 2011, 4, 318-333. [CrossRef] 
40. Walsh, N.C.; Kenney, L.L.; Jangalwe, S.; Aryee, K.-E.; Greiner, D.L.; Brehm, M.A.; Shultz, L.D. Humanized mouse models of clinical disease. Annu. Rev. Pathol. Mech. Dis. 2017, 12, 187-215. [CrossRef] [PubMed]

41. Kawasaki, Y.; Sato, K.; Hayakawa, H.; Takayama, N.; Nakano, H.; Ito, R.; Mashima, K.; Oh, I.; Minakata, D.; Yamasaki, R.; et al. Comprehensive analysis of the activation and proliferation kinetics and effector functions of human lymphocytes, and antigen presentation capacity of antigen-presenting cells in xenogeneic graft-versus-host disease. Biol. Blood Marrow Transplant. 2018, 24, 1563-1574. [CrossRef]

42. King, M.A.; Covassin, L.; Brehm, M.; Racki, W.; Pearson, T.; Leif, J.; Laning, J.; Fodor, W.; Foreman, O.; Burzenski, L.; et al. Human peripheral blood leucocyte non-obese diabetic-severe combined immunodeficiency interleukin-2 receptor gamma chain gene mouse model of xenogeneic graft-versus-host-like disease and the role of host major histocompatibility complex. Clin. Exp. Immunol. 2009, 157, 104-118. [CrossRef]

43. Cooke, K.R.; Kobzik, L.; Martin, T.R.; Brewer, J.; Delmonte, J.; Crawford, J.M.; Ferrara, J.L. An experimental model of idiopathic pneumonia syndrome after bone marrow transplantation: I. The roles of minor H antigens and endotoxin. Blood 1996, 88, 3230-3239. [CrossRef]

44. Ehx, G.; Somja, J.; Warnatz, H.-J.; Ritacco, C.; Hannon, M.; Delens, L.; Fransolet, G.; Delvenne, P.; Muller, J.; Beguin, Y.; et al. Xenogeneic graft-versus-host disease in humanized NSG and NSG-HLA-A2/HHD mice. Front. Immunol. 2018, 9, 1943. [CrossRef] [PubMed]

45. Cuthbertson, P.; Adhikary, S.; Geraghty, N.J.; Guy, T.V.; Hadjiashrafi, A.; Fuller, S.J.; Ly, D.; Watson, D.; Sluyter, R. Increased P2X7 expression in the gastrointestinal tract and skin in a humanised mouse model of graft-versus-host disease. Clin. Sci. 2020, 134, 207-223. [CrossRef]

46. Hannon, M.; Lechanteur, C.; Lucas, S.; Somja, J.; Seidel, L.; Belle, L.; Bruck, F.; Baudoux, E.; Giet, O.; Chantillon, A.-M.; et al. Infusion of clinical-grade enriched regulatory T cells delays experimental xenogeneic graft-versus-host disease. Transfusion 2013, 54, 353-363. [CrossRef] [PubMed]

47. Achita, P.; Dervovic, D.; Ly, D.; Lee, J.B.; Haug, T.; Joe, B.; Hirano, N.; Zhang, L. Infusion of ex-vivo expanded human TCR- $\alpha \beta+$ double-negative regulatory $\mathrm{T}$ cells delays onset of xenogeneic graft-versus -host disease. Clin. Exp. Immunol. 2018, 193, 386-399. [CrossRef]

48. Kanakry, C.G.; Ganguly, S.; Zahurak, M.; Bolaños-Meade, J.; Thoburn, C.; Perkins, B.; Fuchs, E.J.; Jones, R.J.; Hess, A.D.; Luznik, L. Aldehyde dehydrogenase expression drives human regulatory $\mathrm{T}$ cell resistance to posttransplantation cyclophosphamide. Sci. Transl. Med. 2013, 5, 211ra157. [CrossRef]

49. Adhikary, S.R.; Cuthbertson, P.; Nicholson, L.; Bird, K.M.; Sligar, C.; Hu, M.; O'Connell, P.J.; Sluyter, R.; Alexander, S.I.; Watson, D. Post-transplant cyclophosphamide limits reactive donor $\mathrm{T}$ cells and delays the development of graft-versus-host disease in a humanized mouse model. Immunology 2021. [CrossRef] [PubMed]

50. Giuliani, A.L.; Sarti, A.C.; Di Virgilio, F. Extracellular nucleotides and nucleosides as signalling molecules. Immunol. Lett. 2019, 205, 16-24. [CrossRef] [PubMed]

51. Idzko, M.; Ferrari, D.; Eltzschig, H.K. Nucleotide signalling during inflammation. Nature 2014, 509, 310-317. [CrossRef]

52. Borea, P.A.; Gessi, S.; Merighi, S.; Vincenzi, F.; Varani, K. Pharmacology of adenosine receptors: The state of the art. Physiol. Rev. 2018, 98, 1591-1625. [CrossRef]

53. Burnstock, G. P2X ion channel receptors and inflammation. Purinergic Signal. 2016, 12, 59-67. [CrossRef]

54. Le Duc, D.; Schulz, A.; Lede, V.; Schulze, A.; Thor, D.; Brüser, A.; Schöneberg, T. P2Y Receptors in immune response and inflammation. Adv. Immunol. 2017, 136, 85-121. [CrossRef] [PubMed]

55. Jacobson, K.A.; Delicado, E.G.; Gachet, C.; Kennedy, C.; Von Kügelgen, I.; Li, B.; Miras-Portugal, M.T.; Novak, I.; Schöneberg, T.; Perez-Sen, R.; et al. Update of P2Y receptor pharmacology: IUPHAR Review. Br. J. Pharmacol. 2020, 177, 2413-2433. [CrossRef]

56. Yegutkin, G. Enzymes involved in metabolism of extracellular nucleotides and nucleosides: Functional implications and measurement of activities. Crit. Rev. Biochem. Mol. Biol. 2014, 49, 473-497. [CrossRef] [PubMed]

57. Zimmermann, H.; Zebisch, M.; Sträter, N. Cellular function and molecular structure of ecto-nucleotidases. Purinergic Signal. 2012, 8, 437-502. [CrossRef] [PubMed]

58. Antonioli, L.; Pacher, P.; Vizi, E.S.; Haskó, G. CD39 and CD73 in immunity and inflammation. Trends Mol. Med. 2013, 19, 355-367. [CrossRef]

59. Filippin, K.; De Souza, K.F.S.; Júnior, R.T.D.A.; Torquato, H.F.V.; Dias, D.A.; Parisotto, E.B.; Ferreira, A.T.; Paredes-Gamero, E.J. Involvement of $\mathrm{P} 2$ receptors in hematopoiesis and hematopoietic disorders, and as pharmacological targets. Purinergic Signal. 2019, 16, 1-15. [CrossRef] [PubMed]

60. Ratajczak, M.Z.; Adamiak, M.; Bujko, K.; Thapa, A.; Pensato, V.; Kucia, M.; Ratajczak, J.; Ulrich, H. Innate immunity orchestrates the mobilization and homing of hematopoietic stem/progenitor cells by engaging purinergic signaling-An update. Purinergic Signal. 2020, 16, 153-166. [CrossRef]

61. Rossi, L.; Salvestrini, V.; Ferrari, D.; Di Virgilio, F.; Lemoli, R.M. The sixth sense: Hematopoietic stem cells detect danger through purinergic signaling. Blood 2012, 120, 2365-2375. [CrossRef]

62. Antonioli, L.; Fornai, M.; Blandizzi, C.; Pacher, P.; Haskó, G. Adenosine signaling and the immune system: When a lot could be too much. Immunol. Lett. 2019, 205, 9-15. [CrossRef] 
63. Lenkiewicz, A.M.; Adamiak, M.; Thapa, A.; Bujko, K.; Pedziwiatr, D.; Abdel-Latif, A.K.; Kucia, M.; Ratajczak, J.; Ratajczak, M.Z. The Nlrp3 inflammasome orchestrates mobilization of bone marrow-residing stem cells into peripheral blood. Stem Cell Rev. Rep. 2019, 15, 391-403. [CrossRef]

64. Koldej, R.; Collins, J.; Ritchie, D. P2X7 polymorphisms and stem cell mobilisation. Leukemia 2018, 32, 2724-2726. [CrossRef]

65. Adamiak, M.; Bujko, K.; Cymer, M.; Plonka, M.; Glaser, T.; Kucia, M.; Ratajczak, J.; Ulrich, H.; Abdel-Latif, A.; Ratajczak, M.Z. Novel evidence that extracellular nucleotides and purinergic signaling induce innate immunity-mediated mobilization of hematopoietic stem/progenitor cells. Leukemia 2018, 32, 1920-1931. [CrossRef] [PubMed]

66. Ratajczak, M.Z.; Adamiak, M.; Plonka, M.; Abdel-Latif, A.; Ratajczak, J. Mobilization of hematopoietic stem cells as a result of innate immunity-mediated sterile inflammation in the bone marrow microenvironment-The involvement of extracellular nucleotides and purinergic signaling. Leukemia 2018, 32, 1116-1123. [CrossRef]

67. Rossi, L.; Manfredini, R.; Bertolini, F.; Ferrari, D.; Fogli, M.; Zini, R.; Salati, S.; Salvestrini, V.; Gulinelli, S.; Adinolfi, E.; et al. The extracellular nucleotide UTP is a potent inducer of hematopoietic stem cell migration. Blood 2006, 109, 533-542. [CrossRef] [PubMed]

68. Cho, J.; Yusuf, R.; Kook, S.; Attar, E.; Lee, N.; Park, B.; Cheng, T.; Scadden, D.T.; Lee, B.C. Purinergic P2Y 14 receptor modulates stress-induced hematopoietic stem/progenitor cell senescence. J. Clin. Investig. 2014, 124, 3159-3171. [CrossRef] [PubMed]

69. Barbosa, C.M.V.; Leon, C.M.M.P.; Nogueira-Pedro, A.; Wasinsk, F.; Araújo, R.C.; Miranda, A.; Ferreira, A.T.; Paredes-Gamero, E.J. Differentiation of hematopoietic stem cell and myeloid populations by ATP is modulated by cytokines. Cell Death Dis. 2011, 2, e165. [CrossRef] [PubMed]

70. Hirata, Y.; Furuhashi, K.; Ishii, H.; Li, H.W.; Pinho, S.; Ding, L.; Robson, S.C.; Frenette, P.S.; Fujisaki, J. CD150 high bone marrow tregs maintain hematopoietic stem cell quiescence and immune privilege via adenosine. Cell Stem Cell 2018, 22, 445-453.e5. [CrossRef] [PubMed]

71. Deotare, U.; Al-Dawsari, G.; Couban, S.; Lipton, J.H. G-CSF-primed bone marrow as a source of stem cells for allografting: Revisiting the concept. Bone Marrow Transplant. 2015, 50, 1150-1156. [CrossRef]

72. Wilhelm, K.; Ganesan, J.; Müller, T.; Dürr, C.; Grimm, M.; Beilhack, A.; Krempl, C.D.; Sorichter, S.; Gerlach, U.V.; Jüttner, E.; et al. Graft-versus-host disease is enhanced by extracellular ATP activating P2X7R. Nat. Med. 2010, 16, 1434-1438. [CrossRef]

73. Dürr, C.; Follo, M.; Idzko, M.; Reichardt, W.; Zeiser, R. Graft-versus-host disease reduces regulatory T-cell migration into the tumour tissue. Immunology 2012, 137, 80-88. [CrossRef]

74. Cymer, M.; Brzeźniakiewicz-Janus, K.; Bujko, K.; Thapa, A.; Ratajczak, J.; Anusz, K.; Tracz, M.; Jackowska-Tracz, A.; Ratajczak, M.Z.; Adamiak, M. Pannexin-1 channel "fuels" by releasing ATP from bone marrow cells a state of sterile inflammation required for optimal mobilization and homing of hematopoietic stem cells. Purinergic Signal. 2020, 16, 313-325. [CrossRef]

75. Granell, M.; Urbano-Ispizua, Á.; Pons, A.; Aróstegui, J.I.; Gel, B.; Navarro, A.; Jansa, S.; Artells, R.; Gaya, A.; Talarn, C.; et al. Common variants in NLRP2 and NLRP3 genes are strong prognostic factors for the outcome of HLA-identical sibling allogeneic stem cell transplantation. Blood 2008, 112, 4337-4342. [CrossRef] [PubMed]

76. Lee, K.-H.; Park, S.S.; Kim, I.; Kim, J.H.; Ra, E.K.; Yoon, S.-S.; Hong, Y.-C.; Kim, B.K. P2X7 receptor polymorphism and clinical outcomes in HLA-matched sibling allogeneic hematopoietic stem cell transplantation. Haematologica 2007, 92, 651-657. [CrossRef] [PubMed]

77. Karaesmen, E.; Rizvi, A.A.; Preus, L.M.; McCarthy, P.L.; Pasquini, M.C.; Onel, K.; Zhu, X.; Spellman, S.; Haiman, C.A.; Stram, D.O.; et al. Replication and validation of genetic polymorphisms associated with survival after allogeneic blood or marrow transplant. Blood 2017, 130, 1585-1596. [CrossRef]

78. Koldej, R.M.; Perera, T.; Collins, J.; Ritchie, D.S. Association between P2X7 polymorphisms and post-transplant outcomes in allogeneic haematopoietic stem cell transplantation. Int. J. Mol. Sci. 2020, 21, 3772. [CrossRef] [PubMed]

79. Vaisitti, T.; Arruga, F.; Guerra, G.; Deaglio, S. Ectonucleotidases in blood malignancies: A tale of surface markers and therapeutic targets. Front. Immunol. 2019, 10, 2301. [CrossRef]

80. De Marchi, E.; Pegoraro, A.; Adinolfi, E. P2X7 receptor in hematological malignancies. Front. Cell Dev. Biol. $2021,9,645605$. [CrossRef]

81. Linden, J.; Koch-Nolte, F.; Dahl, G. Purine release, metabolism, and signaling in the inflammatory response. Annu. Rev. Immunol. 2019, 37, 325-347. [CrossRef]

82. Apostolova, P.; Zeiser, R. The role of danger signals and ectonucleotidases in acute graft-versus-host disease. Hum. Immunol. 2016, 77, 1037-1047. [CrossRef]

83. Cekic, C.; Linden, J. Purinergic regulation of the immune system. Nat. Rev. Immunol. 2016, 16, 177-192. [CrossRef] [PubMed]

84. Sáez, P.J.; Vargas, P.; Shoji, K.F.; Harcha, P.A.; Lennon-Duménil, A.-M.; Sáez, J.C. ATP promotes the fast migration of dendritic cells through the activity of pannexin 1 channels and P2X7 receptors. Sci. Signal. 2017, 10, eaah7107. [CrossRef] [PubMed]

85. Englezou, P.C.; Rothwell, S.W.; Ainscough, J.S.; Brough, D.; Landsiedel, R.; Verkhratsky, A.; Kimber, I.; Dearman, R.J. P2X7R activation drives distinct IL-1 responses in dendritic cells compared to macrophages. Cytokine 2015, 74, 293-304. [CrossRef] [PubMed]

86. Yip, L.; Woehrle, T.; Corriden, R.; Hirsh, M.; Chen, Y.; Inoue, Y.; Ferrari, V.; Insel, P.A.; Junger, W.G. Autocrine regulation of T-cell activation by ATP release and P2X 7 receptors. FASEB J. 2009, 23, 1685-1693. [CrossRef] 
87. Müller, T.; Robaye, B.; Vieira, R.P.; Ferrari, D.; Grimm, M.; Jakob, T.; Martin, S.F.; Di Virgilio, F.; Boeynaems, J.-M.; Virchow, J.C.; et al. The purinergic receptor $\mathrm{P} 2 \mathrm{Y} 2$ receptor mediates chemotaxis of dendritic cells and eosinophils in allergic lung inflammation. Allergy 2010, 65, 1545-1553. [CrossRef]

88. Stachon, P.; Geis, S.; Peikert, A.; Heidenreich, A.; Michel, N.A.; Ünal, F.; Hoppe, N.; Dufner, B.; Schulte, L.; Marchini, T.; et al. Extracellular ATP induces vascular inflammation and atherosclerosis via purinergic receptor Y2 in mice. Arter. Thromb. Vasc. Biol. 2016, 36, 1577-1586. [CrossRef] [PubMed]

89. Higgins, K.R.; Kovacevic, W.; Stokes, L. Nucleotides regulate secretion of the inflammatory chemokine CCL2 from human macrophages and monocytes. Mediat. Inflamm. 2014, 2014, 1-13. [CrossRef]

90. De La Rosa, G.; Gómez, A.I.; Baños, M.C.; Pelegrín, P. Signaling through purinergic receptor P2Y ${ }_{2}$ enhances macrophage IL-1 $\beta$ production. Int. J. Mol. Sci. 2020, 21, 4686. [CrossRef]

91. Lappas, C.M.; Rieger, J.M.; Linden, J. A2A adenosine receptor induction inhibits IFN- $\gamma$ production in murine CD4+T cells. J. Immunol. 2005, 174, 1073-1080. [CrossRef] [PubMed]

92. Sorrentino, C.; Hossain, F.; Rodriguez, P.C.; Sierra, R.A.; Pannuti, A.; Hatfield, S.; Osborne, B.A.; Minter, L.M.; Miele, L.; Morello, S. Adenosine A2A receptor stimulation inhibits TCR-induced Notch1 activation in CD8+T-cells. Front. Immunol. 2019, 10, 162. [CrossRef]

93. Alnouri, M.W.; Jepards, S.; Casari, A.; Schiedel, A.C.; Hinz, S.; Müller, C.E. Selectivity is species-dependent: Characterization of standard agonists and antagonists at human, rat, and mouse adenosine receptors. Purinergic Signal. 2015, 11, 389-407. [CrossRef]

94. Donnelly-Roberts, D.L.; Namovic, M.T.; Han, P.; Jarvis, M.F. Mammalian P2X7 receptor pharmacology: Comparison of recombinant mouse, rat and human P2X7 receptors. Br. J. Pharmacol. 2009, 157, 1203-1214. [CrossRef] [PubMed]

95. Sluyter, R. The P2X7 receptor. Adv. Exp. Med. Biol. 2017, 1051, 17-53. [CrossRef]

96. Qiu, F.; Dahl, G. A permeant regulating its permeation pore: Inhibition of pannexin 1 channels by ATP. Am. J. Physiol. Physiol. 2009, 296, C250-C255. [CrossRef]

97. Tokumitsu, H.; Chijiwa, T.; Hagiwara, M.; Mizutani, A.; Terasawa, M.; Hidaka, H. KN-62, 1-[N,O-bis(5-isoquinolinesulfonyl)-Nmethyl-L-tyrosyl]-4-phenylpiperazi ne, a specific inhibitor of Ca2+/calmodulin-dependent protein kinase II. J. Biol. Chem. 1990, 265, 4315-4320. [CrossRef]

98. Gargett, C.E.; Wiley, J. The isoquinoline derivative KN-62 a potent antagonist of the P2Z-receptor of human lymphocytes. Br. J. Pharmacol. 1997, 120, 1483-1490. [CrossRef]

99. Spaulding, A.; Rutherford, G.W.; Siegfried, N. Stavudine or zidovudine in three-drug combination therapy for initial treatment of HIV infection in antiretroviral-naïve individuals. Cochrane Database Syst. Rev. 2010, CD008651. [CrossRef]

100. Fowler, B.J.; Gelfand, B.D.; Kim, Y.; Kerur, N.; Tarallo, V.; Hirano, Y.; Amarnath, S.; Fowler, D.H.; Radwan, M.; Young, M.T.; et al. Nucleoside reverse transcriptase inhibitors possess intrinsic anti-inflammatory activity. Science 2014, 346, 1000-1003. [CrossRef] [PubMed]

101. Al-Khalidi, R.; Panicucci, C.; Cox, P.; Chira, N.; Róg, J.; Young, C.N.J.; McGeehan, R.E.; Ambati, K.; Ambati, J.; Zablocki, K.; et al. Zidovudine ameliorates pathology in the mouse model of Duchenne muscular dystrophy via P2RX7 purinoceptor antagonism. Acta Neuropathol. Commun. 2018, 6, 1-17. [CrossRef]

102. Bhattarai, S.; Freundlieb, M.; Pippel, J.; Meyer, A.; Abdelrahman, A.; Fiene, A.; Lee, S.-Y.; Zimmermann, H.; Yegutkin, G.; Sträter, N.; et al. $\alpha, \beta$-methylene-ADP (AOPCP) derivatives and analogues: Development of potent and selective ecto-5'nucleotidase (CD73) inhibitors. J. Med. Chem. 2015, 58, 6248-6263. [CrossRef] [PubMed]

103. Covarrubias, R.; Chepurko, E.; Reynolds, A.; Huttinger, Z.M.; Huttinger, R.; Stanfill, K.; Wheeler, D.G.; Novitskaya, T.; Robson, S.C.; Dwyer, K.M.; et al. Role of the CD39/CD73 purinergic pathway in modulating arterial thrombosis in mice. Arter. Thromb. Vasc. Biol. 2016, 36, 1809-1820. [CrossRef] [PubMed]

104. Brown, P.; Dale, N. Modulation of $\mathrm{K}+$ currents in Xenopus spinal neurons by p2y receptors: A role for ATP and ADP in motor pattern generation. J. Physiol. 2002, 540, 843-850. [CrossRef]

105. Müller, C.E.; Iqbal, J.; Baqi, Y.; Zimmermann, H.; Röllich, A.; Stephan, H. Polyoxometalates-A new class of potent ecto-nucleoside triphosphate diphosphohydrolase (NTPDase) inhibitors. Bioorganic Med. Chem. Lett. 2006, 16, 5943-5947. [CrossRef]

106. Pimenta-Dos-Reis, G.; Torres, E.J.L.; Quintana, P.G.; Vidal, L.O.; Dos Santos, B.A.F.; Lin, C.-S.; Heise, N.; Persechini, P.M.; Schachter, J. POM-1 inhibits P2 receptors and exhibits anti-inflammatory effects in macrophages. Purinergic Signal. 2017, 13, 611-627. [CrossRef] [PubMed]

107. Pizzirani, C.; Falzoni, S.; Govoni, M.; La Corte, R.; Donadei, S.; Di Virgilio, F.; Trotta, F.; Monaco, A.L. Dysfunctional inflammasome in Schnitzler's syndrome. Rheumatology 2009, 48, 1304-1308. [CrossRef]

108. Wang, Y.; Chen, Z.; Liu, C.; Lu, X.; Yang, C.; Qiu, S. Distributive differences of P2Xs between the forelimb and hind limb of adjuvant arthritis rats and intervention by Notopterygh rhizoma et radix. Pharm. Biol. 2019, 57, 81-88. [CrossRef]

109. Denlinger, L.C.; Manthei, D.M.; Seibold, M.A.; Ahn, K.; Bleecker, E.; Boushey, H.A.; Calhoun, W.J.; Castro, M.; Chinchili, V.M.; Fahy, J.V.; et al. P2X7-regulated protection from exacerbations and loss of control is independent of asthma maintenance therapy. Am. J. Respir. Crit. Care Med. 2013, 187, 28-33. [CrossRef]

110. Koehn, B.H.; Saha, A.; McDonald-Hyman, C.; Loschi, M.; Thangavelu, G.; Ma, L.; Zaiken, M.C.; Dysthe, J.; Krepps, W.; Panthera, J.; et al. Danger-associated extracellular ATP counters MDSC therapeutic efficacy in acute GVHD. Blood 2019, 134, 1670-1682. [CrossRef] 
111. Tsukamoto, H.; Chernogorova, P.; Ayata, K.; Gerlach, U.V.; Rughani, A.; Ritchey, J.W.; Ganesan, J.; Follo, M.; Zeiser, R.; Thompson, L.F.; et al. Deficiency of CD73/ecto-5' -nucleotidase in mice enhances acute graft-versus-host disease. Blood 2012, 119, $4554-4564$. [CrossRef]

112. Wang, L.; Fan, J.; Chen, S.; Zhang, Y.; Curiel, T.J.; Zhang, B. Graft-versus-host disease is enhanced by selective CD73 blockade in mice. PLoS ONE 2013, 8, e58397. [CrossRef]

113. Geraghty, N.J.; Watson, D.; Sluyter, R. Pharmacological blockade of the CD39/CD73 pathway but not adenosine receptors augments disease in a humanized mouse model of graft- versus -host disease. Immunol. Cell Biol. 2019, 97, 597-610. [CrossRef]

114. Zhong, X.; Zhu, F.; Qiao, J.; Zhao, K.; Zhu, S.; Zeng, L.; Chen, X.; Xu, K. The impact of P2X7 receptor antagonist, brilliant blue G on graft-versus-host disease in mice after allogeneic hematopoietic stem cell transplantation. Cell. Immunol. 2016, 310, 71-77. [CrossRef] [PubMed]

115. Chen, S.; Smith, B.; Iype, J.; Prestipino, A.; Pfeifer, D.; Grundmann, S.; Schmitt-Graeff, A.; Idzko, M.; Beck, Y.; Prinz, G.; et al. MicroRNA-155-deficient dendritic cells cause less severe GVHD through reduced migration and defective inflammasome activation. Blood 2015, 126, 103-112. [CrossRef] [PubMed]

116. Huang, F.; Chen, M.; Chen, W.; Gu, J.; Yuan, J.; Xue, Y.; Dang, J.; Su, W.; Wang, J.; Zadeh, H.; et al. Human gingiva-derived mesenchymal stem cells inhibit xeno-graft-versus-host disease via CD39-CD73-Adenosine and IDO Signals. Front. Immunol. 2017, 8, 68. [CrossRef] [PubMed]

117. Cuthbertson, P.; Geraghty, N.J.; Adhikary, S.R.; Casolin, S.; Watson, D.; Sluyter, R. P2X7 receptor antagonism increases regulatory $\mathrm{T}$ cells and reduces clinical and histological graft-versus-host disease in a humanised mouse model. Clin. Sci. 2021, 135, 495-513. [CrossRef]

118. Geraghty, N.J.; Belfiore, L.; Ly, D.; Adhikary, S.; Fuller, S.J.; Varikatt, W.; Sanderson-Smith, M.; Sluyter, V.; Alexander, S.I.; Watson, D. The P2X7 receptor antagonist Brilliant Blue G reduces serum human interferon- $\gamma$ in a humanized mouse model of graft-versus-host disease. Clin. Exp. Immunol. 2017, 190, 79-95. [CrossRef]

119. Geraghty, N.; Watson, D.; Sluyter, R. Long-term treatment with the P2X7 receptor antagonist Brilliant Blue G reduces liver inflammation in a humanized mouse model of graft-versus-host disease. Cell. Immunol. 2019, 336, 12-19. [CrossRef]

120. Adhikary, S.; Geraghty, N.; Cuthbertson, P.; Sluyter, R.; Watson, D. Altered donor P2X7 activity in human leukocytes correlates with P2RX7 genotype but does not affect the development of graft-versus-host disease in humanised mice. Purinergic Signal. 2019, 15, 177-192. [CrossRef]

121. Da Silva, H.B.; Beura, L.K.; Wang, H.; Hanse, E.A.; Gore, R.; Scott, M.C.; Walsh, D.A.; Block, K.E.; Fonseca, R.; Yan, Y.; et al. The purinergic receptor P2RX7 directs metabolic fitness of long-lived memory CD8+ T cells. Nature 2018, 559, 264-268. [CrossRef] [PubMed]

122. Da Silva, H.B.; Peng, C.; Wang, H.; Wanhainen, K.M.; Ma, C.; Lopez, S.; Khoruts, A.; Zhang, N.; Jameson, S.C. Sensing of ATP via the purinergic receptor P2RX7 promotes CD8+ Trm cell generation by enhancing their sensitivity to the cytokine TGF- $\beta$. Immunity 2020, 53, 158-171.e6. [CrossRef]

123. Schenk, U.; Frascoli, M.; Proietti, M.; Geffers, R.; Traggiai, E.; Buer, J.; Ricordi, C.; Westendorf, A.M.; Grassi, F. ATP inhibits the generation and function of regulatory T cells through the activation of purinergic P2X receptors. Sci. Signal. 2011, 4, ra12. [CrossRef] [PubMed]

124. Koehn, B.H.; Apostolova, P.; Haverkamp, J.M.; Miller, J.S.; McCullar, V.; Tolar, J.; Munn, D.; Murphy, W.J.; Brickey, W.J.; Serody, J.S.; et al. GVHD-associated, inflammasome-mediated loss of function in adoptively transferred myeloid-derived suppressor cells. Blood 2015, 126, 1621-1628. [CrossRef]

125. Klämbt, V.; Wohlfeil, S.; Schwab, L.; Hülsdünker, J.; Ayata, K.; Apostolova, P.; Schmitt-Graeff, A.; Dierbach, H.; Prinz, G.; Follo, M.; et al. A Novel function for P2Y2 in myeloid recipient-derived cells during graft-versus-host disease. J. Immunol. 2015, 195, 5795-5804. [CrossRef] [PubMed]

126. Munir, S.Z.; Aylward, J. A review of ocular graft-versus-host disease. Optom. Vis. Sci. 2017, 94, 545-555. [CrossRef]

127. Pupovac, A.; Sluyter, R. Roles of extracellular nucleotides and P2 receptors in ectodomain shedding. Cell. Mol. Life Sci. 2016, 73, 4159-4173. [CrossRef]

128. Sakimoto, T.; Ohnishi, T.; Ishimori, A. Significance of ectodomain shedding of TNF receptor 1 in ocular surface. Investig. Opthalmology Vis. Sci. 2014, 55, 2419-2423. [CrossRef] [PubMed]

129. Ohashi, Y.; Munesue, M.; Shimazaki, J.; Takamura, E.; Yokoi, N.; Watanabe, H.; Nomura, A.; Shimada, F. Long-term safety and effectiveness of diquafosol for the treatment of dry eye in a real-world setting: A prospective observational study. Adv. Ther. 2020, 37, 707-717. [CrossRef]

130. Yang, S.; Sheng, X.; Xiang, D.; Wei, X.; Chen, T.; Yang, Z.; Zhang, Y. CD150 high treg cells may attenuate graft versus host disease and intestinal cell apoptosis after hematopoietic stem cell transplantation. Am. J. Transl. Res. 2019, 11, 1299-1310.

131. Rissiek, A.; Baumann, I.; Cuapio, A.; Mautner, A.; Kolster, M.; Arck, P.C.; Dodge-Khatami, A.; Mittrücker, H.-W.; Koch-Nolte, F.; Haag, F.; et al. The expression of CD39 on regulatory T cells is genetically driven and further upregulated at sites of inflammation. J. Autoimmun. 2015, 58, 12-20. [CrossRef]

132. Adhikary, S.R.; Cuthbertson, P.; Turner, R.J.; Sluyter, R.; Watson, D. A single-nucleotide polymorphism in the human ENTPD1 gene encoding CD39 is associated with worsened graft-versus-host disease in a humanized mouse model. Immunol. Cell Biol. 2020, 98, 397-410. [CrossRef] [PubMed] 
133. Lappas, C.M.; Liu, P.-C.; Linden, J.; Kang, E.M.; Malech, H. Adenosine A2A receptor activation limits graft-versus-host disease after allogenic hematopoietic stem cell transplantation. J. Leukoc. Biol. 2009, 87, 345-354. [CrossRef] [PubMed]

134. Han, K.L.; Thomas, S.V.M.; Koontz, S.M.; Changpriroa, C.M.; Ha, S.-K.; Malech, H.L.; Kang, E.M. Adenosine A2A receptor agonist-mediated increase in donor-derived regulatory $\mathrm{t}$ cells suppresses development of graft-versus-host disease. J. Immunol. 2012, 190, 458-468. [CrossRef]

135. Amarnath, S.; Foley, J.E.; Farthing, D.E.; Gress, R.E.; Laurence, A.; Eckhaus, M.A.; Métais, J.-Y.; Rose, J.J.; Hakim, F.T.; Felizardo, T.C.; et al. Bone marrow-derived mesenchymal stromal cells harness purinergenic signaling to tolerize human Th1 cells in vivo. Stem Cells 2015, 33, 1200-1212. [CrossRef] [PubMed]

136. Geraghty, N.; Adhikary, S.; Watson, D.; Sluyter, R. The A2A receptor agonist CGS 21680 has beneficial and adverse effects on disease development in a humanised mouse model of graft-versus-host disease. Int. Immunopharmacol. 2019, 72, 479-486. [CrossRef] [PubMed] 